\title{
Seasonal features and origins of carbonaceous aerosols at Syowa Station, coastal Antarctica
}

\author{
Keiichiro Hara ${ }^{1}$, Kengo Sudo ${ }^{2}$, Takato Ohnishi ${ }^{2}$, Kazuo Osada ${ }^{2}$, Masanori Yabuki ${ }^{3}$, Masataka Shiobara ${ }^{4}$, and \\ Takashi Yamanouchi ${ }^{4}$ \\ ${ }^{1}$ Department of Earth System Science, Faculty of Science, Fukuoka University, Fukuoka, 814-0180, Japan \\ ${ }^{2}$ Graduate School of Environmental Studies, Nagoya University, Nagoya, 464-8601, Japan \\ ${ }^{3}$ Research Institute for Sustainable Humanosphere, Kyoto University, Kyoto, 611-0011, Japan \\ ${ }^{4}$ National Institute of Polar Research, Tokyo, 190-0014, Japan
}

Correspondence: Keiichiro Hara (harakei@ fukuoka-u.ac.jp)

Received: 13 November 2018 - Discussion started: 7 January 2019

Revised: 18 March 2019 - Accepted: 2 May 2019 - Published: 12 June 2019

\begin{abstract}
We have measured black carbon (BC) concentrations at Syowa Station, Antarctica, since February 2005. The measured BC concentrations in 2005-2016 were corrected to equivalent $\mathrm{BC}(\mathrm{EBC})$ concentrations using Weingartner's method. Seasonal features of EBC concentrations, long-range transport from mid-latitudes to the Antarctic coast, and their origins were characterized. Results show that daily median EBC concentrations were below the detection limit $\left(0.2 \mathrm{ng} \mathrm{m}^{-3}\right)$ to $63.8 \mathrm{ng} \mathrm{m}^{-3}$ at Syowa Station (median, $1.8 \mathrm{ng} \mathrm{m}^{-3}$; mean, $2.7 \mathrm{ng} \mathrm{m}^{-3}$ during the measurement period of February 2005-December 2016). Although seasonal features and year-to-year variations in EBC concentrations were observed, no long-term trend of EBC concentrations was clear during our measurement period. Seasonal features of EBC concentrations showed a spring maximum during September-October at Syowa Station. To elucidate EBC transport processes, origins, and the potential source area (PSA), we compared EBC data to backward trajectory analysis and chemical transport model simulation. From comparison with backward trajectory, high EBC concentrations were found in air masses from the marine boundary layer. This finding implies that transport via the marine boundary layer was the most important transport pathway to EBC concentrations at Antarctic coasts. Some EBC was supplied to the Antarctic region by transport via the upper free troposphere. Chemical transport model simulation demonstrated that the most important origins and PSA of EBC at Syowa Station were biomass burning in South America and southern Africa. Fossil fuel combustion in South America and south-
\end{abstract}

ern Africa also have important contributions. The absorption Ångström exponent (AAE) showed clear seasonal features with 0.5-1.0 during April-October and maximum (1.0-1.5) in December-February. The AAE features might be associated with organic aerosols and mixing states of EBC.

\section{Introduction}

Carbonaceous aerosols are major aerosols in the troposphere (e.g. Gelencsér, 2004; Gilardoni and Fuzzi, 2017). In general, carbonaceous aerosols include organic compounds and particulate graphite (e.g. Gelencsér, 2004; Andreae and Gelencsér, 2006; Bond et al., 2013). Various terms such as elemental carbon (EC), black carbon (BC), organics, and soot are used to describe carbonaceous particles. Apart from secondary organics associated with biogenic cycles, most carbonaceous aerosols (e.g. soot) can be released from combustion of biomass and fuels. Soot particles consist of refractory and insoluble matter (a.k.a. EC) and organics (e.g. Andreae and Gelencsér, 2006). As defined by Novakov (1984), BC comprises particulate graphitic particles. Recently, $\mathrm{BC}$ has been defined by the following physical properties: (1) strong light absorption, (2) refractory, (3) insoluble, and (4) including aggregates of small carbon spherules (e.g. Bond et al., 2013). Because of its strong optical absorption, $\mathrm{BC}$ has been a concern for atmospheric radiation budgets and climate effects (e.g. Bond et al., 2013, references therein). In addition to BC, mineral particles containing iron oxides (e.g. hematite and 
magnetite) and some organic aerosols (e.g. brown carbon, $\mathrm{BrC}$ ) have light absorption in visible and ultraviolet (UV) spectral bands (Bond et al., 2013, references therein; Moteki et al., 2017). Furthermore, BC can alter surface albedo after deposition onto snow surfaces in polar regions (e.g. Flanner et al., 2007; Aoki et al., 2011; Hadley and Kirchstetter, 2012; Bond et al., 2013). In the Antarctic region, BC effects on radiation budgets are regarded as negligible because of low BC concentration (e.g. Warren and Clarke, 1990; Bodhaine, 1995; Weller et al., 2013).

Atmospheric BC is released directly from incomplete combustion processes. The Antarctic region is isolated from large combustion sources related to human activities at low latitudes and mid-latitudes. Therefore, local origins of BC in the Antarctic area are limited to (1) human activity at research stations, (2) usage of snow vehicles for travel, (3) operations of airplanes and research vessels during summer, and (4) ship-borne tourism mainly on the Antarctic Peninsula (Shirsat and Graf, 2009; Graf et al., 2010). Although local contamination from these sources can engender temporarily high BC concentrations (e.g. Wolff and Cachier, 1998; Hansen et al., 2001; Hagler et al., 2008), the BC source strength is likely to be negligible or only slight throughout the Antarctic region. Indeed, earlier work has shown that $\mathrm{BC}$ concentrations are lower at higher latitudes (Wolff and Cachier, 1998; Weller et al., 2013). It has been considered that BC must be supplied from outside of Antarctica, i.e. long-range transport, to maintain the background $\mathrm{BC}$ level and that it has seasonal features in the Antarctic atmosphere because of the low BC source strength in the Antarctic region. In other words, $\mathrm{BC}$ in the Antarctic atmosphere is useful as a tracer of atmospheric substances derived from combustion processes occurring at mid-latitudes and low latitudes.

Earlier studies (Wolff and Cachier, 1998; Weller et al., 2013) have pointed out the likelihood that BC in the Antarctic atmosphere originates from biomass burning. Additionally, BC is transported directly from South America (Fiebig et al., 2009; Hara et al., 2010) and from southern Africa (Hara et al., 2010) by poleward flow associated with cyclone activity in the Southern Ocean. Additionally, Weller et al. (2013) and Pereira et al. (2006) demonstrated that BC at Neumayer and Ferraz is supplied from biomass burning in South America. Considering BC outflow from South America and southern Africa and local emission from tourism, we must consider the longitudinal distribution of $\mathrm{BC}$ in western and eastern Antarctica to compare and elucidate BC concentrations measured at each station and transport pathway to the Antarctic. Levoglucosan, as a tracer of biomass burning, was detected in aerosol and snow samples taken from the Antarctic (Gambaro et al., 2008; Hu et al., 2013; Zangrando et al., 2016). Therefore, the BC must be transported from areas where the biomass burning occurred. In fact, BC records for the past 150 years in the Antarctic ice cores (WAIS core in western Antarctica and Law Dome core in eastern Antarc- tica) showed influences by the El Niño-Southern Oscillation (ENSO) and BC emissions from biomass burning and human activity in the source areas (Bisiaux et al., 2012; Arienzo et al., 2017). Furthermore, high correlation between BC and $\mathrm{NH}_{4}^{+}$in the Antarctic ice core indicates $\mathrm{BC}$ and $\mathrm{NH}_{4}^{+}$from primary sources of biomass burning (Pasteris et al., 2014). Certainly, BC measurements taken over a few decades at Neumayer indicate an unclear long-term trend of BC concentrations, although a slight decreasing trend is apparent in summer (Weller et al., 2013).

In contrast to the Arctic atmosphere, earlier works concluded that anthropogenic effects were only slight and negligible for aerosols in the Antarctic atmosphere (e.g. Weller et al., 2011, 2013), although some anthropogenic metals such as $\mathrm{Pb}$ have been found in snow and ice cores in the Antarctic region (Planchon et al., 2002; Vallelonga et al., 2002). Considering that biomass burning occurs on the ground in forests and grasslands, anthropogenic BC (derived mainly from fossil fuel combustion) can be transported to Antarctica. With the recent intense economic development of countries of the Southern Hemisphere, the contributions of anthropogenic BC must be assessed. Nevertheless, the contributions of biomass burning and anthropogenic processes to $\mathrm{BC}$ concentrations in the Antarctic troposphere and their PSA have been neither quantitatively analysed nor discussed in the relevant literature.

To elucidate $\mathrm{BC}$ transport from the low latitudes and mid-latitudes to the Antarctic region, we must ascertain the potential source area (PSA) and transport pathway. Actually, BC cannot be vaporized in ambient conditions. Therefore, $\mathrm{BC}$ must be transported from the origins (i.e. combustion processes) to the Antarctic. However, chemical analyses such as isotope ratio investigations are difficult to apply for identification of $\mathrm{BC}$ origins because the major $\mathrm{BC}$ component is graphite. Hara et al. (2010) described BC transport from South America and southern Africa to Syowa Station, Antarctica. Similarly to BC, mineral particles are transported from their origins to Antarctica, except for local emissions originating within the Antarctic Circle. For identification of the origins of mineral particles, earlier studies have been conducted to analyse and assess PSA of mineral particles based on $\mathrm{Nd} / \mathrm{Sr}$ isotope ratios (Smith et al., 2003; Delmonte et al., 2004, 2008; Bory et al., 2010; Vallelonga et al., 2010; Aarons et al., 2016), Pb isotope ratios (De Deckker et al., 2010; Chang et al., 2016: Gili et al., 2016), rareearth element patterns (Gabrielli et al., 2010; Vallelonga et al., 2010; Wegner et al., 2012; Aarons et al., 2016), and trajectories or models (Pereira et al., 2004; Li et al., 2010; Albani et al., 2012; Gassó et al., 2010; Krinner et al., 2010; Neff and Bertler, 2015). From the aspect of mineral particles transported into Antarctica, South America (mostly Patagonia) has been identified as the most dominant PSA, whereas Australia and Africa respectively show minor and unimportant PSAs (e.g. Neff and Bertler, 2015). Although one must consider the following differences between $\mathrm{BC}$ and minerals, 
(1) geographical locations of PSA, (2) seasonality of source strength, and (3) size of aerosol particles containing BC and minerals, $\mathrm{BC}$ can be transported by outflow from the continents in the mid-latitudes to Antarctica. Here, we combine BC measurements with backward trajectory and chemical transport model simulation. This study was conducted to elucidate $\mathrm{BC}$ origins and PSA and to characterize BC concentrations and their seasonal features at Syowa Station, Antarctica, located in the Indian Ocean sector.

\section{Measurements, modelling, and analysis}

\subsection{Aerosol measurements at Syowa Station, Antarctica}

Aerosol measurements were conducted as part of the Japanese Antarctic Research Expedition (JARE) at Syowa Station on eastern Ongul Island, Antarctica $\left(69^{\circ} 00^{\prime} \mathrm{S}\right.$, $39^{\circ} 35^{\prime} \mathrm{E}$, ca. $29 \mathrm{~m}$ above sea level), located as presented in Fig. 1. To Syowa, the icebreaker ship Shirase approaches every summer (mainly the end of December to early February) for the transportation of fuel and materials to support wintering operations and scientific activity. Some airplanes and helicopters operate occasionally during summer and not during other seasons. In contrast to the situation on the Antarctic Peninsula, ship-borne tourism was not done off Syowa during our measurements because of the station's distance from the other continents and the long distance between Syowa and the sea-ice margin (ca. $100 \mathrm{~km}$ even in summer). The BC concentrations have been measured using a multiwavelength Aethalometer (AE31; Magee Scientific) since February 2005, although the Aethalometer measurements were not taken from January 2007 through January 2008 because of instrumental troubles. For this study, we used BC data measured in 2005-2016. The wavelengths of light sources in the Aethalometer were 370, 470, 520, 590, 660, 880 , and $950 \mathrm{~nm}$. The Aethalometer was operated in a clean air observatory located on the windward side of prevailing winds, ca. $400 \mathrm{~m}$ distant from the main area of Syowa, where a diesel power station was operating. The Aethalometer operated under the following conditions: flow rate (ca. $9 \mathrm{~L} \mathrm{~min}^{-1}$ in 2005-2006 and ca. $11 \mathrm{~L} \mathrm{~min}^{-1}$ in 2008-present), data record resolution of $15 \mathrm{~min}$, and spot change every $24 \mathrm{~h}$. For this study, we used a high-sensitivity AE31 instrument. The area of a circular spot to accumulate aerosols on the filter tape was $60.3 \pm 1 \mathrm{~mm}^{2}$.

In an Aethalometer, $\mathrm{BC}$ concentrations are measured by light attenuation resulting from optical absorption of $\mathrm{BC}$ collected on the filter tape. As earlier works have suggested (e.g. Weingartner et al., 2003; Collaud Coen et al., 2010; Bond et al., 2013), the filter-based BC measurements have scattering and shadowing effects that can engender error of $\mathrm{BC}$ measurements. Therefore, we used Weingartner's procedures for this study to correct BC concentrations (Weingartner et al.,

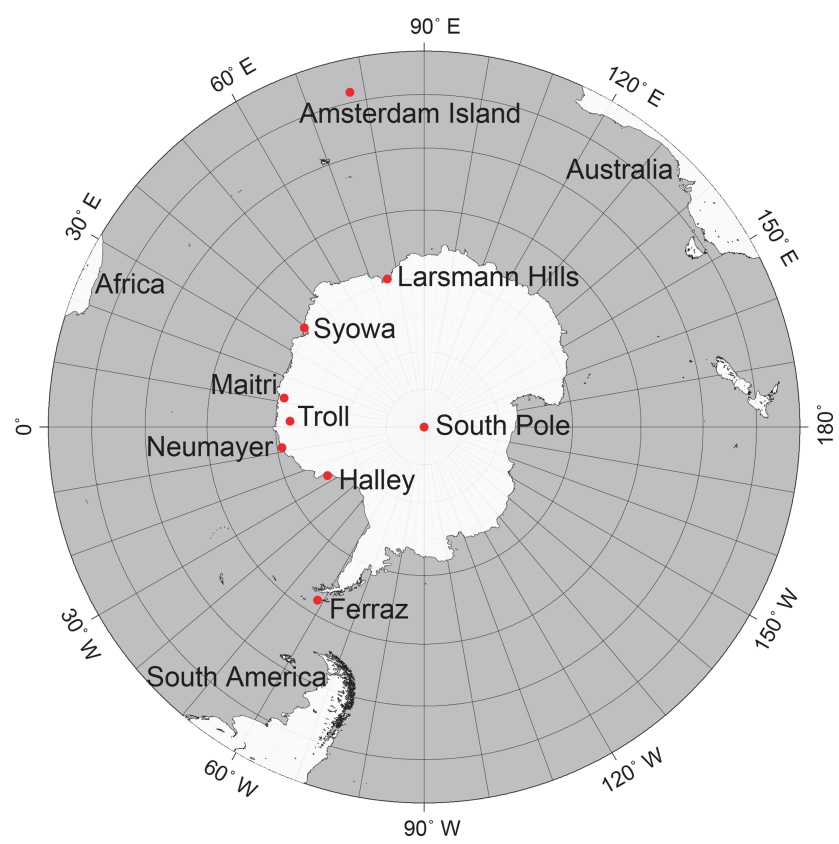

Figure 1. Locations of Syowa Station and other research stations with BC measurements in Antarctica and the Southern Ocean. Red circles represent locations of each station.

2003). Details of procedures for correction of BC concentrations are presented in Supplement. Light attenuation and optical attenuation coefficients in UV and visible ranges can be influenced greatly by optical absorption of organics and mineral dusts (e.g. Bond et al., 2013). Attenuation at $880 \mathrm{~nm}$ is used widely for BC retrievals. Therefore, for this study, we used attenuation data in the IR channel $(\lambda=880 \mathrm{~nm})$ to estimate the $\mathrm{BC}$ concentrations. As reported by Bond et al. (2013), hereinafter we use the term equivalent BC (EBC) for the corrected $\mathrm{BC}$ mass concentrations and the measured $\mathrm{BC}$ concentrations using filter-based optical techniques from earlier works. The detection limit of EBC in the Aethalometer depends on the optical signal-to-noise ratio. We checked the optical signal-to-noise ratios of aerosol-free conditions several times in our measurement conditions. The detection limit was estimated as $0.2 \mathrm{ng} \mathrm{m}^{-3}$ in the IR channel under our measurement conditions $(\Delta t=120 \mathrm{~min}$ and flow rate, $10 \mathrm{~L} \mathrm{~min}^{-1}$ ). Uncertainty of the measured EBC concentrations relates to (1) stability of the optical signal, (2) flow rate control, (3) spot area, and (4) scattering and shadowing effects. The detection limit value corresponds to uncertainty resulting from processes of (1)-(3). Uncertainty by the process (4) depends on the aerosol number concentrations and optical properties (single scattering albedo). The EBC concentrations corrected using Weingartner's method were mostly lower by $0.5-2 \%$ compared to the uncorrected EBC concentrations in this study (Fig. S1). Less difference between the corrected and uncorrected EBC concentrations might derive from higher single scattering albedo and replacement of the 
filter spot before optical attenuation reaches $10 \%$ in most cases in our measurement conditions at Syowa.

Using multi-wavelength optical absorption values by aerosols retrieved using the Aethalometer, we estimated the absorption Ångström exponent (AAE) in this study. The values of AAE can be represented as

$C_{\mathrm{abs}}(\lambda)=b_{\mathrm{abs}} \lambda^{-\mathrm{AAE}}$,

where $C_{\mathrm{abs}}$ and $b_{\mathrm{abs}}$ respectively represent the optical absorption cross section at the $\lambda$ (wavelength) and optical absorption coefficient. First, $b_{\mathrm{abs}}$ or $b_{\mathrm{ATN}}$ (optical attenuation coefficient) must be known to estimate AAE (Supplement). Then, we estimated AAE in the UV-IR range (370-950 nm) and the visible (Vis)-IR range (590-950 nm) to elucidate the effects of organics and EBC on optical absorption properties.

When winds come from the main area of the station, aerosol data can be contaminated considerably. Before data analysis and discussion, BC data were screened using wind data (direction and speed) provided by the Japan Meteorological Agency and using condensation nuclei $(\mathrm{CN})$ concentrations obtained from JARE aerosol monitoring data by the following procedures. First, we estimated 10 min mean $\mathrm{CN}$ concentrations from raw $\mathrm{CN}$ data with $1 \mathrm{~min}$ resolution to identify local contamination events. When wind flowed from contaminable sector (wind direction of $180-330^{\circ}$ ) and the wind speed was less than $2 \mathrm{~m} \mathrm{~s}^{-1}$, the 10 min mean $\mathrm{CN}$ data were removed as "locally contaminated data". Furthermore, the 10 min mean $\mathrm{CN}$ data were also screened in cases of relative standard deviation larger than $10 \%$ in 10 min mean estimation under conditions with wind speed less than $15 \mathrm{~m} \mathrm{~s}^{-1}$ because of the likelihood of local contamination from moving contamination sources such as snow vehicles. For wind speeds greater than $15 \mathrm{~m} \mathrm{~s}^{-1}$ corresponding to storm conditions, the $\mathrm{CN}$ data were retained as "non-locally contaminated". Operation of snow vehicles was not permitted during strong winds because of safety guidelines at Syowa. Additionally, stronger winds came from the prevailing wind direction (mainly $0-80^{\circ}$ : clean air sector). Therefore, local contamination was not included in cases of stronger winds. Then, EBC and AAE data were filtered using the screened $\mathrm{CN}$ data. When local contamination was identified in $\mathrm{CN}$ data within $2 \mathrm{~h}$, the EBC data were removed as "locally contaminated".

\subsection{Analysis of air mass history and origins}

For this study, the $120 \mathrm{~h}$ backward trajectory was computed to elucidate the transport pathway and origins of air masses transported to Syowa. The backward trajectory was calculated using the model vertical velocity mode in the NOAAHYSPLIT model with meteorological data from the NCEP reanalysis (Stein et al., 2015). The initial point was at an altitude of $500 \mathrm{~m}$ above ground level over Syowa, Antarctica. For comparison between hourly mean EBC concentrations and the air mass history, the backward trajectory was calculated every hour from January 2005 through December 2016 in this study. Here, we use the following criteria to divide each air mass origin: marine, $<66^{\circ} \mathrm{S}$; coastal, 66 $75^{\circ} \mathrm{S}$; Antarctic-continental, $>75^{\circ} \mathrm{S}$; boundary layer (BL), $<1500 \mathrm{~m}$; free troposphere $(\mathrm{FT}),>1500 \mathrm{~m}$. Then, times passing in each area such as marine BL (MBL), coastal BL, continental BL, continental FT, coastal FT, and marine FT (MFT) were counted for each backward trajectory. The areas with air masses staying for the longest times in the 5-day backward trajectory were identified as air mass origins.

\subsection{CHASER (MIROC-ESM) model}

Chemical atmospheric global climate model for studies of atmospheric environment and radiative forcing (CHASER) (Sudo et al., 2002; Sudo and Akimoto, 2007), developed mainly at Nagoya University and the Japan Agency for Marine-Earth Science and Technology (JAMSTEC), is a coupled chemistry climate model (CCM) simulating atmospheric chemistry and aerosols. Aerosols are examined using the Spectral Radiation-Transport Model for Aerosol Species (SPRINTARS) module (Takemura et al., 2005). It has also been developed in the framework of the Model for Interdisciplinary Research On Climate (MIROC) - Earth System Model (ESM), MIROC-ESM-CHEM (Watanabe et al., 2011). CHASER simulates details of chemistry in the troposphere and stratosphere with an online aerosol simulation including the production of particulate nitrate and secondary organic aerosols. As a standard configuration, the model's horizontal resolution is selected as T42 $\left(2.8^{\circ} \times 2.8^{\circ}\right)$, with 57 layers extending vertically from the surface up to about $55 \mathrm{~km}$ altitude. Regarding the overall model structure, CHASER is fully coupled with the climate model core MIROC, permitting atmospheric constituents (both gases and aerosols) to interact radiatively and hydrologically with meteorological fields in the model. The chemistry component of CHASER includes consideration of the $\mathrm{O}_{x}-\mathrm{NO}_{x}-\mathrm{HO}_{x}-\mathrm{CH}_{4}-\mathrm{CO}$ chemical system with oxidation of non-methane volatile organic carbons (NMVOCs), halogen chemistry, and the $\mathrm{NH}_{x}-\mathrm{SO}_{x}-\mathrm{NO}_{3}$ system. In all, 96 chemical species and 287 chemical reactions are considered. In the model, primary NMVOCs include $\mathrm{C}_{2} \mathrm{H}_{6}, \mathrm{C}_{2} \mathrm{H}_{4}, \mathrm{C}_{3} \mathrm{H}_{8}$, $\mathrm{C}_{3} \mathrm{H}_{6}, \mathrm{C}_{4} \mathrm{H}_{1} 0$, acetone, methanol, and biogenic NMVOCs (isoprene, terpenes). For the present study, CHASER uses interannually constant anthropogenic emissions (EDGARHTAP2-2008, http://edgar.jrc.ec.europa.eu/htap_v2/, last access: 20 May 2019) with the biomass burning emission dataset (MACC reanalysis). Regional biomass burning emissions and their seasonal trends in MACC are similar to those in other inventories (e.g. GFED), although slight differences exist in the regional distribution of biomass burning in each inventory. The model was nudged to the NCEP FNL ds083 $(u, v, T)$ and HadiSST/ICE (2000-2017).

The aerosol component of CHASER considers BC tracers of two types: hydrophobic $\mathrm{BC}$ (in external mixture) and 
hydrophilic BC (internally mixed with water-soluble species such as organics or $\mathrm{SO}_{4}^{2-}$ ). In the latest model version, the aging process of $\mathrm{BC}$ in which hydrophobic $\mathrm{BC}$ is converted gradually to hydrophilic is simulated considering the condensation of sulfuric acid $\left(\mathrm{H}_{2} \mathrm{SO}_{4}\right)$ and semi-volatile organic carbons onto the $\mathrm{BC}$ surface, and coagulation of $\mathrm{BC}$ with watersoluble particles (organics, $\mathrm{SO}_{4}^{2}$, etc.). The current model configuration calculates $\mathrm{BC}$ aging with time constants of less than one day in the PBLs, and a few days or weeks in the free troposphere depending on the abundances in $\mathrm{SO}_{2}$, volatile organic carbons, and water-soluble aerosols.

For this study, a tagged BC tracer simulation is newly introduced into CHASER for estimating the respective contributions from different regions and types of emission to the long-range transport of $\mathrm{BC}$. The tagged $\mathrm{BC}$ simulation, performed basically in the same framework of the tagged $\mathrm{O}_{3}$ simulation developed by Sudo and Akimoto (2007), separates the globe into 15 regions as presented in Fig. 2 and calculates transport and deposition of $\mathrm{BC}$ emitted from the regions as distinct tracers. For the individual $\mathrm{BC}$ tracers, we also discriminate different emission sectors: (1) biomass burning, (2) fossil-fuel combustion, and (3) others (such as cooking and open burning). The tagged $\mathrm{BC}$ emissions are first injected into the atmosphere as hydrophobic BC (in external mixture). They then undergo aging processes to be converted to hydrophilic $\mathrm{BC}$ as described above. To avoid confusion of the term (e.g. EBC), we use the term $\mathrm{mBC}$ hereinafter to designate the simulated mass $\mathrm{BC}$ concentrations.

\section{Results and discussion}

\subsection{Variations in EBC at Syowa Station, Antarctica}

Figure 3 depicts seasonal features of EBC concentrations at Syowa Station, Antarctica, from February 2005 through December 2016. In this study, median EBC concentrations are used for discussion because the mean EBC concentrations can be overestimated relative to ambient EBC concentrations without local contamination when the unfilterable data derived from local contamination were present in our data screening procedures. Daily median EBC concentrations ranged from below the detection limit $\left(<0.2 \mathrm{ng} \mathrm{m}^{-3}\right)$ to $63.8 \mathrm{ng} \mathrm{m}^{-3}$ during the measurement period. Modal, median, and mean concentrations were, respectively, 1.1, 1.8, and $2.7 \mathrm{ng} \mathrm{m}^{-3}$ (Fig. S2). In addition, the distributions of EBC concentrations were approximated by lognormal distributions $\left(R^{2}=0.9983\right)$ as

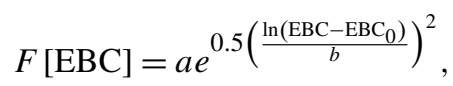

where $a, b$, and $\mathrm{EBC}_{0}$ respectively stand for $529.75,0.7270$, and 1.12. High EBC concentrations were often observed in winter-spring during 2005-2009. Measurement conditions (e.g. tube length and room temperature) and analytical procedures were the same from 2005-2016. Therefore, this change might result from variations in the frequency or strength of EBC transport events rather than measurement and analytical reasons.

From trend analysis (Supplement and Fig. S3), a very slight decreasing trend $\left(-0.036 \mathrm{ng} \mathrm{m}^{-3} \mathrm{yr}^{-1}, p=0.0145\right)$ was observed in our measurements for 2005-2016. However, an increasing trend $\left(0.105 \mathrm{ng} \mathrm{m}^{-3} \mathrm{yr}^{-1}, p<0.001\right)$ was obtained in 2010-2016. These trend values included temporal trends, as explained below. Therefore, we concluded only slightly whether these trends were long-term EBC trends or not. More continuous EBC measurements must be taken at Syowa Station to analyse long-term trends. Although a decreasing trend of EBC concentrations in summer (November and December) was found at Neumayer (Weller et al., 2013), no seasonal long-term trend was clear at Syowa except for in July (Fig. S4). At a glance, EBC concentrations in July showed an increasing trend for 2011-2016 $\left(0.325 \mathrm{ng} \mathrm{m}^{-3} \mathrm{yr}^{-1}\right.$ in monthly median and $0.363 \mathrm{ng} \mathrm{m}^{-3} \mathrm{yr}^{-1}$ in monthly mean). However, we must consider the likelihood that EBC concentrations in winter (June-August) declined in 2010-2012 rather than following the increasing trend by EBC emissions at middle and low latitudes. Indeed, this variation in July might be related to changes in air mass origins (details are discussed in Sect. 3.2).

Before comparison between our EBC data and EBC concentrations measured at the other Antarctic stations, we must consider observation procedures and data quality of EBC in earlier works. Although different instruments were used for EBC measurements among Syowa (7-wavelength Aethalometer, AE31), Halley (Aethalometer, AE10), Neumayer (Aethalometer: AE10 and multi-angle absorption photometer, MAAP), and South Pole (particulate soot absorption photometer, PSAP), the EBC measurement principles were similar (i.e. filter-based optical attenuation measurement). In earlier works, EBC concentrations were uncorrected, unlike this study. The EBC concentrations corrected using Weingartner's method decreased mostly by $0.5 \%-2 \%$ compared to the uncorrected EBC concentrations in this study (Fig. S2). The lesser difference between the corrected and uncorrected EBC concentrations might result from (1) higher single scattering albedo and (2) replacement of filter spot before optical attenuation reaching to $10 \%$ in most cases in our measurement conditions at Syowa. Therefore, we can compare EBC concentrations in this study to the uncorrected EBC concentrations measured at other Antarctic stations in previous works. In addition to filter-based EBC measurements, a single-particle soot photometer (SP2) has been used for the measurement of refractory BC (rBC) (e.g. Bond et al., 2013; Sharma et al., 2017). According to Sharma et al. (2017), high correlation with $R^{2}=0.8-0.9$ and slopes $=1.2-1.6$ was observed between $\mathrm{rBC}$ and EBC in aerosols in the Arctic, where aerosol concentrations and anthropogenic effects were greater and stronger than those in Antarctica. Considering different conditions of aerosol chemistry and optical proper- 


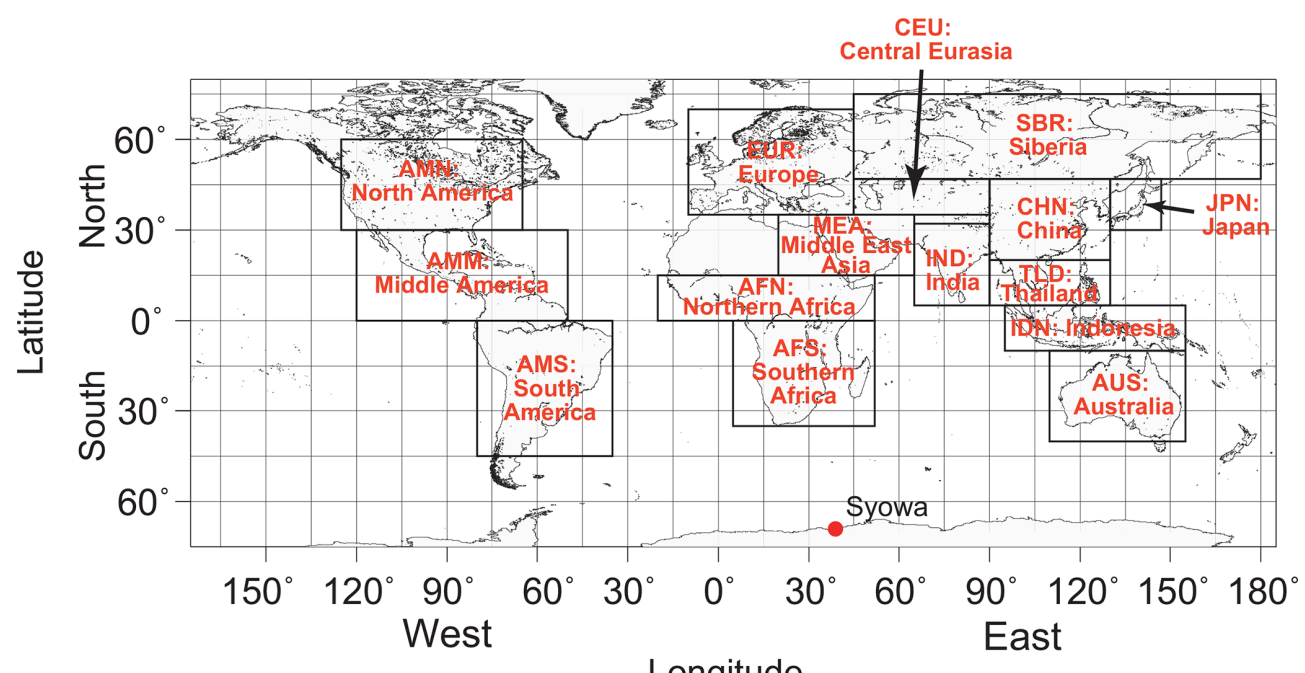

Figure 2. Regional separation for BC tracer tagging. The red circle represents the location of Syowa Station, Antarctica.

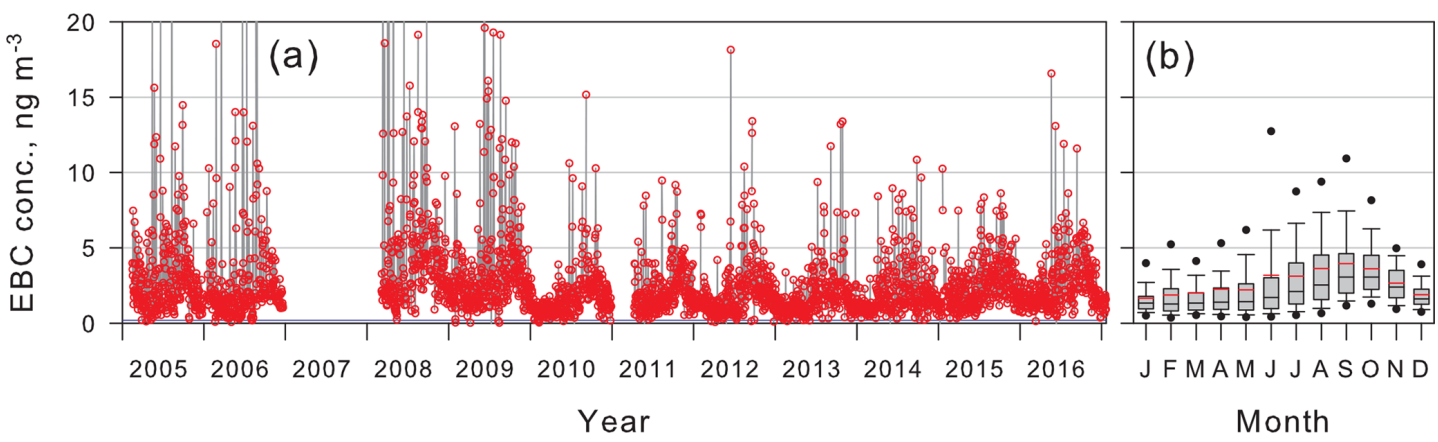

Figure 3. Seasonal features of (a) daily median EBC concentrations and (b) monthly box plot of EBC concentrations at Syowa from February 2005. EBC concentrations were not available in January 2007-January 2008 and January 2011-early April 2011 because of mechanical troubles with the Aethalometer. The blue line in (a) shows the detection limit $\left(0.2 \mathrm{ng} \mathrm{m}^{-3}\right)$ in our measurements. In box plots, the upper bar, upper box line, black middle box line, bottom box line, and bottom bar respectively denote values of $90 \%, 75 \%, 50 \%$ (median), $25 \%$, and $10 \%$. The red line shows mean values.

ties between those in Antarctica and the Arctic, correlation in the Antarctic is expected to be different from that in the Arctic. No report of the relevant literature has described SP2 used to measure $\mathrm{rBC}$ year-round in the Antarctic region. Because of higher single-scattering albedo and lower aerosol concentrations in the Antarctic, differences between $\mathrm{rBC}$ and EBC might not be greater than in the Arctic.

The EBC concentrations were similar to the EBC concentrations measured at coastal stations such as Halley and Neumayer (Wolff and Cahier, 1998; Weller et al., 2013). In contrast, EBC concentrations at Ferraz, Maitri, and Larsemann Hills were higher than those at Syowa (Pereira et al., 2006; Chaubey et al., 2010). Ferraz is located in the northern area of the Antarctic Peninsula as presented in Fig. 1. Air masses at Ferraz were transported frequently from South America (Pereira et al., 2004), so that the long-range transport from South America might engender higher EBC concentrations at Ferraz than those at other Antarctic coast locations. The
EBC concentrations at Maitri and Larsemann Hills during summer were markedly higher than those at Syowa and Neumayer. Considering the geographical locations of these stations, as presented in Fig. 1, the high EBC concentrations at Maitri and Larsemann Hills might result from insufficient screening of data contaminated locally by human activity, as pointed out by Weller et al. (2013). Therefore, we concluded that EBC concentrations observed at Syowa corresponded to background EBC concentrations at the Antarctic coasts in the Indian Ocean sector.

Measurements of EBC concentrations exhibited clear seasonal features at Syowa with a maximum (median, $3.1 \mathrm{ng} \mathrm{m}^{-3}$ ) in August-November and a minimum $\left(1.3 \mathrm{ng} \mathrm{m}^{-3}\right)$ in January and February-April (Fig. 3). Moreover, EBC concentrations at Syowa started increasing gradually in June and July. The spring maximum mainly in October-November was also observed at Halley, Neumayer, and the South Pole (Bodhaine, 1995; Wolff and Cachier, 
1998; Weller et al., 2013). EBC measurements at Ferraz on the Antarctic Peninsula showed high EBC concentrations in September-January (Pereira et al., 2006). Therefore, similar seasonal features at all stations cannot be explained by local phenomena. Consequently, the spring EBC maximum might occur on the scale of the entire Antarctic region. Moreover, the spring EBC maximum appeared in a slightly earlier month at Syowa than in the periods examined at the other stations such as Neumayer. In addition to the spring maximum (October-November), a second maximum of EBC concentrations was found in summer (February-March/April) at Neumayer (Weller et al., 2013) and Ferraz (Pereira et al., 2006). However, the second EBC maximum was not identified clearly at Syowa.

As pointed out by earlier studies (e.g. Wolff and Cachier, 1998; Fiebig et al., 2009; Hara et al., 2010; Weller et al., 2013), biomass burning in the middle latitudes and low latitudes has been regarded as having dominant origins of EBC measured in the Antarctic troposphere. Biomass burning in the Southern Hemisphere occurs in Africa, South America, Australia, and Indonesia (Edwards et al., 2006a, b; Ito et al., 2007; Giglio et al., 2013). The burned area in each PSA increased drastically during July-September in Africa, August-October in South America, and SeptemberNovember in Australia (Giglio et al., 2013). Considering that land-origin species such as EBC and mineral dusts can outflow eastwardly to the Southern Ocean because of cyclone activity and movement (e.g. Edwards et al., 2006a; Fiebig et al., 2009; Hara et al., 2010), the contribution of biomass burning from each PSA likely depends on where the respective coastal stations are located (e.g. sectors of the Atlantic, Indian, and Pacific oceans). For example, brief transport from southern Africa might occur rarely at Neumayer and Halley, although brief transport was observed at Syowa (Hara et al., 2010). Therefore, the difference of the month in the spring EBC maximum (August-November at Syowa, October-November at the other stations) might be associated with the seasonal variations in biomass burning in each PSA and transport pathway and processes to the Antarctic coasts. In addition to biomass burning, anthropogenic processes (i.e. combustion of fossil fuel) must be discussed because anthropogenic EBC can outflow simultaneously from the continents in the mid-latitudes. Details of BC transport and origins will be discussed in Sect. 3.3 and 3.4.

\subsection{Air mass origins at Syowa Station, Antarctica}

As described above, EBC concentrations at Syowa were found to show clear seasonal variations. To elucidate the seasonal features, we must compare the seasonal features of EBC concentrations to seasonal variations in transport processes and EBC source strength in the Southern Hemisphere. Figure 4 depicts density maps of end points of the 5day backward trajectory (i.e. air mass origins in this study). The transport pathway is classifiable roughly into (1) pole- ward flow from the Southern Ocean, (2) westward flow along the coastline, and (3) outflow from the high-latitudinal Antarctic continent to the coasts. These flow patterns were identified throughout the year at Syowa. In the poleward flow from the ocean, air masses were transported mostly from the Atlantic Ocean at $>40^{\circ} \mathrm{S}$ and from the Indian Ocean at $>50^{\circ} \mathrm{S}$ within $5 \mathrm{~d}$, although transport from the Atlantic Ocean at ca. $30^{\circ} \mathrm{S}$ was identified in some cases. The poleward flow patterns were important through the year. In addition, the poleward flow patterns were associated with the eastward approach of cyclones off Syowa (Hara et al., 2010). These flow patterns corresponded to EBC transport pathway to the Antarctic coasts suggested by Fiebig et al. (2009) and Hara et al. (2010). In westward flows, the air mass origins for the prior $5 \mathrm{~d}$ were distributed to the Antarctic coasts of approx. $150^{\circ} \mathrm{E}$. Although some air masses at $150^{\circ} \mathrm{E}$ were transported even in winter, the density around the coasts at $140-150^{\circ} \mathrm{E}$ was higher in summer, particularly during November-January. Wintering research stations such as Mawson $\left(67^{\circ} 36^{\prime} \mathrm{S}, 62^{\circ} 52^{\prime} \mathrm{E}\right)$, Zhongshang $\left(69^{\circ} 22^{\prime} \mathrm{S}, 76^{\circ} 22^{\prime} \mathrm{E}\right)$, and Dumont d'Urville $\left(66^{\circ} 40^{\prime} \mathrm{S}\right.$, $140^{\circ} 00^{\prime} \mathrm{E}$ ) operated at the coasts at $40-150^{\circ} \mathrm{E}$. Although EBC can be emitted from these stations by human activity, Syowa is too distant to have any strong effect on EBC concentrations by local EBC emissions in these stations, as suggested by Hagler et al. (2008), because of the slight EBC source strength. Furthermore, outflows from the Antarctic continent were observed throughout the year. The trajectory density on the Antarctic continent was especially lower at high latitudes during summer. Outflow from the highlatitudinal Antarctic continent was observed under conditions with clear skies and weak winds at Syowa resulting from anticyclone influence, as described by Hara et al. (2011, 2013). By contrast, the air mass origins were distributed extensively in the Southern Oceans and Antarctic continent during winter. This difference implies that the transport strength of the outflow from the Antarctic continent showed remarkable seasonal change in addition to the important contribution of the poleward flow patterns from the ocean. Furthermore, air masses came occasionally from the Pacific Ocean sector across the Antarctic continent.

To understand the spatial and vertical motion of air masses, Fig. 5 shows vertical density plots of the trajectory. In the cases of poleward flow from the ocean, air masses passed through the lower troposphere, mainly in the MBL and partly in the lower free troposphere (LFT). By contrast, air masses came mostly from the FT over the Antarctic continent. In addition to the descent flow, air masses near the surface on the continent were also transported to Syowa during winter. Most end points of the backward trajectories over the continent were distributed up to ca. $4000 \mathrm{~m}$ during summer. However, the distribution of the end points was expanded to ca. $6000 \mathrm{~m}$ over the continent during winter. It is noteworthy that the vertical density maps are shown using the height above ground level. Considering tropopause height 

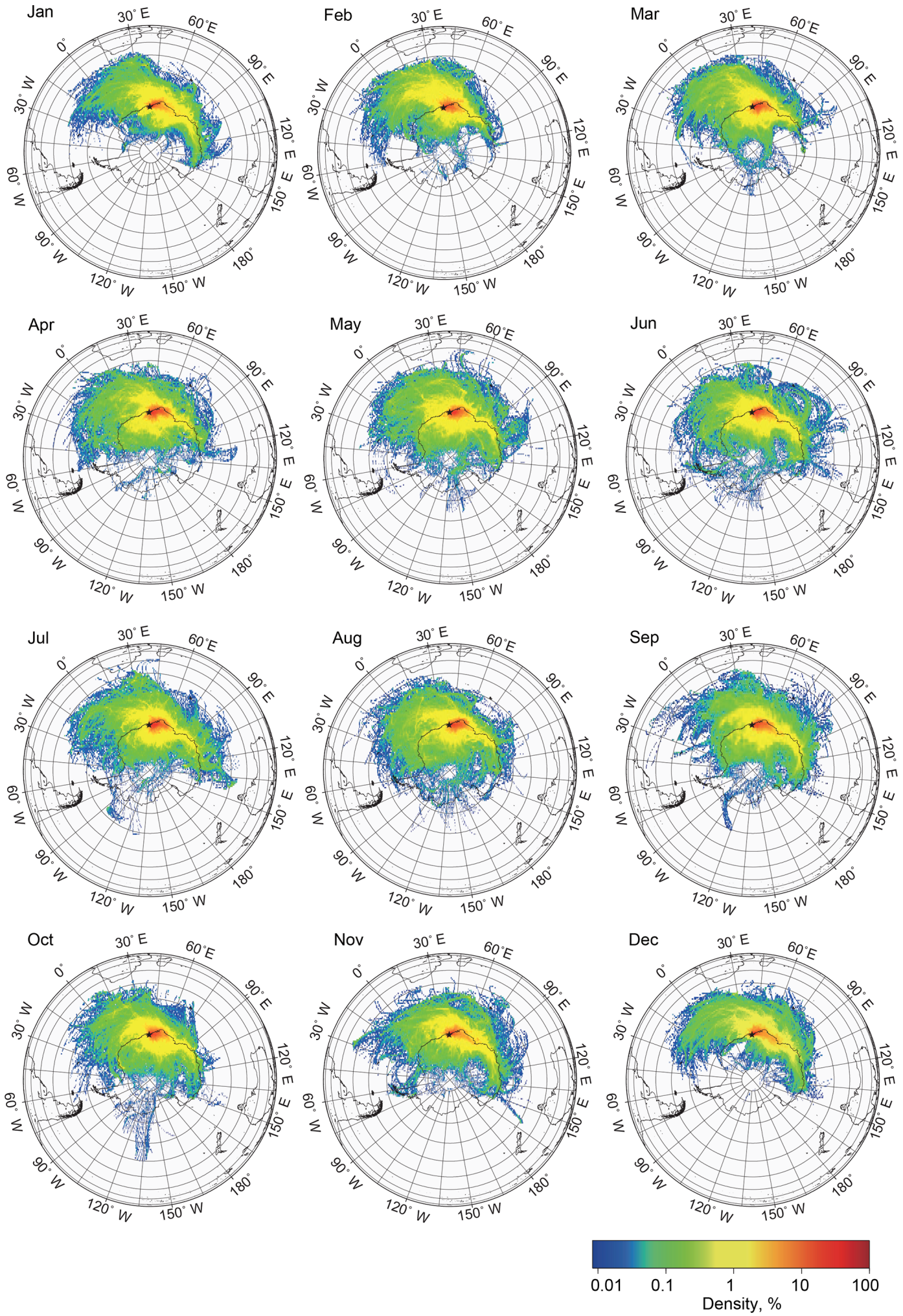

Figure 4. Density map of air mass origins in each month at Syowa Station. Black stars denote the respective locations of Syowa Station. 
$(8-10 \mathrm{~km})$ identified by $\mathrm{O}_{3}$ profiles in the Antarctic during the winter (Tomikawa et al., 2009), the air mass history implies that air masses near tropopause over the continent can flow to the BL at the Antarctic coasts during winter. This seasonal difference indicates that vertical mixing in the outflow from the Antarctic continent was stronger in the winter than in summer. At latitudes of around $70^{\circ} \mathrm{S}$, high density was identified below 2000-3000 m. Therefore, air masses in the westward flow passed through the lower troposphere during the summer. With suggestion of vertical motion and geographical classification of air mass origins as described above, the following transport patterns and air mass origins at Syowa are finally classifiable in this study: (1) poleward flow from MBL, (2) poleward flow from LFT, (3) westward flow along the coastal line via BL, (4) westward flow along the coastal line from LFT, (5) outflow from the FT over the Antarctic continent, and (6) outflow from BL over the Antarctic continent.

As described above, EBC is expected to be supplied mostly from outside of Antarctica. Plausible transport pathways are transport via MBL and FT. We must know the EBC concentrations of each air mass origin (MBL, coastal $\mathrm{BL}$, continental BL, continental FT, coastal FT, and MFT) to elucidate EBC transport pathway to the Antarctic. Figure 6 depicts seasonal features of air mass origins in each month and monthly mean and median EBC concentrations at Syowa during our measurements (2005-2016). The dominant air mass origins were MBL, coastal BL, coastal FT, and continental FT. The most dominant air mass origins were MBL and coastal BL in November-February. In addition to MBL and coastal BL, the contributions of transport from coastal FT and continental FT increased in February/MarchOctober at Syowa, although year-to-year differences were found in the seasonal variations in air mass origins. In particular, the contribution of transport from continental FT in March-October was higher than that in other years. This change corresponded to lower EBC concentrations in July of 2010-2012, as described above. Therefore, the increasing trend in EBC concentrations in July of 2010-2016 might not be a long-term trend but a temporal trend resulting from yearto-year variations in air mass history.

\subsection{EBC concentrations in respective air mass origins}

We compared the EBC concentrations at Syowa with the air mass history (origins) to elucidate EBC transport processes to the Antarctic coasts and EBC spatial distribution in Antarctica. The backward trajectories were computed every hour. For comparison between EBC concentrations and air mass origins, hourly mean EBC concentrations were estimated. Then, hourly EBC data were classified into each air mass origin. The hourly mean EBC concentration for each air mass origin is presented in Fig. 7. The respective EBC concentrations in MBL and marine FT were higher than those in continental FT and BL. The differences in EBC concen- trations for each air mass origin might reflect the latitudinal gradient and spatial distribution of EBC. This latitudinal gradient was found to be consistent with results reported from earlier works (Hansen et al., 1988; Bodhaine, 1995; Wolff and Cachier, 1998; Weller et al., 2013). Because of the lower (negligible) EBC source strength on the Antarctic continent, latitudinal distributions might result from dilution during transport from low latitudes and mid-latitudes and dry and wet deposition of EBC onto the snow surface.

Measurements show that EBC concentrations in each air mass origin were higher in September-November. In particular, EBC concentrations in MBL increased gradually during May-June. Seasonal features of EBC concentrations in MBL (Fig. 7a) might correspond to those in the MBL in the Southern Ocean in Atlantic and Indian sectors, considering that air masses were transported dominantly via MBL from the mid-latitudes by the cyclone approach. Although few EBC measurements were made through the year in the Southern Ocean, EBC concentrations in Amsterdam Islands (midlatitude in the Indian Ocean: $37^{\circ} 50^{\prime} \mathrm{S}, 77^{\circ} 30^{\prime} \mathrm{E}$ ) showed strong seasonal variations in EBC concentrations with a maximum in July-September (Wolf and Cachier, 1998; Sciare et al., 2009). Previous ship-borne EBC measurements showed EBC concentrations of $<10 \mathrm{ng} \mathrm{m}^{-3}$ in January-April over the southern Indian Ocean $\left(<56^{\circ} \mathrm{S}\right)$ (Moorthy et al., 2005), and $20-80 \mathrm{ng} \mathrm{m}^{-3}$ in October-December over the Indian Ocean and Southern Ocean (34-59 ${ }^{\circ}$ S) (Sakerin et al., 2007). In MBL of the southern Atlantic Ocean (close to South America) to the Southern Ocean, the EBC concentrations were $<10-160 \mathrm{ng} \mathrm{m}^{-3}$ in October-November and $<10$ $120 \mathrm{ng} \mathrm{m}^{-3}$ in February-March (Evangelista et al., 2007). Although we must consider the geographical locations of these EBC measurements, these EBC concentrations were several times to 10 times higher than the background EBC concentrations at the Antarctic coasts, and corresponded to higher EBC concentrations at Syowa in the cases of poleward transport via MBL and MFT.

Although high EBC concentrations were obtained in air masses from MBL, we must consider EBC origins in air masses from MBL. Additionally, $120 \mathrm{~h}$ backward trajectory analysis was too short to reach to contributable PSA because it took longer than one week for transport from the coasts of South America and southern Africa to Syowa (Hara et al., 2010). The density of marine traffic (i.e. ship operation) in the Southern Ocean and near the Antarctic coasts was too low to engender an increase in EBC concentrations in air mass from MBL, although ship emissions can have an influence locally on EBC concentrations, for example ship-borne tourism in the Antarctic Peninsula during summer. Furthermore, seasonal variations and distributions of $\mathrm{CO}$ concentrations in the Southern Hemisphere exhibited the spring maximum corresponding to outflow from the continents and fire counts in each PSA (Gros et al., 1999; Edwards et al., 2006a, b). In addition, Edwards et al. (2006a) reported that high CO concentrations in Africa appeared in earlier months than those 

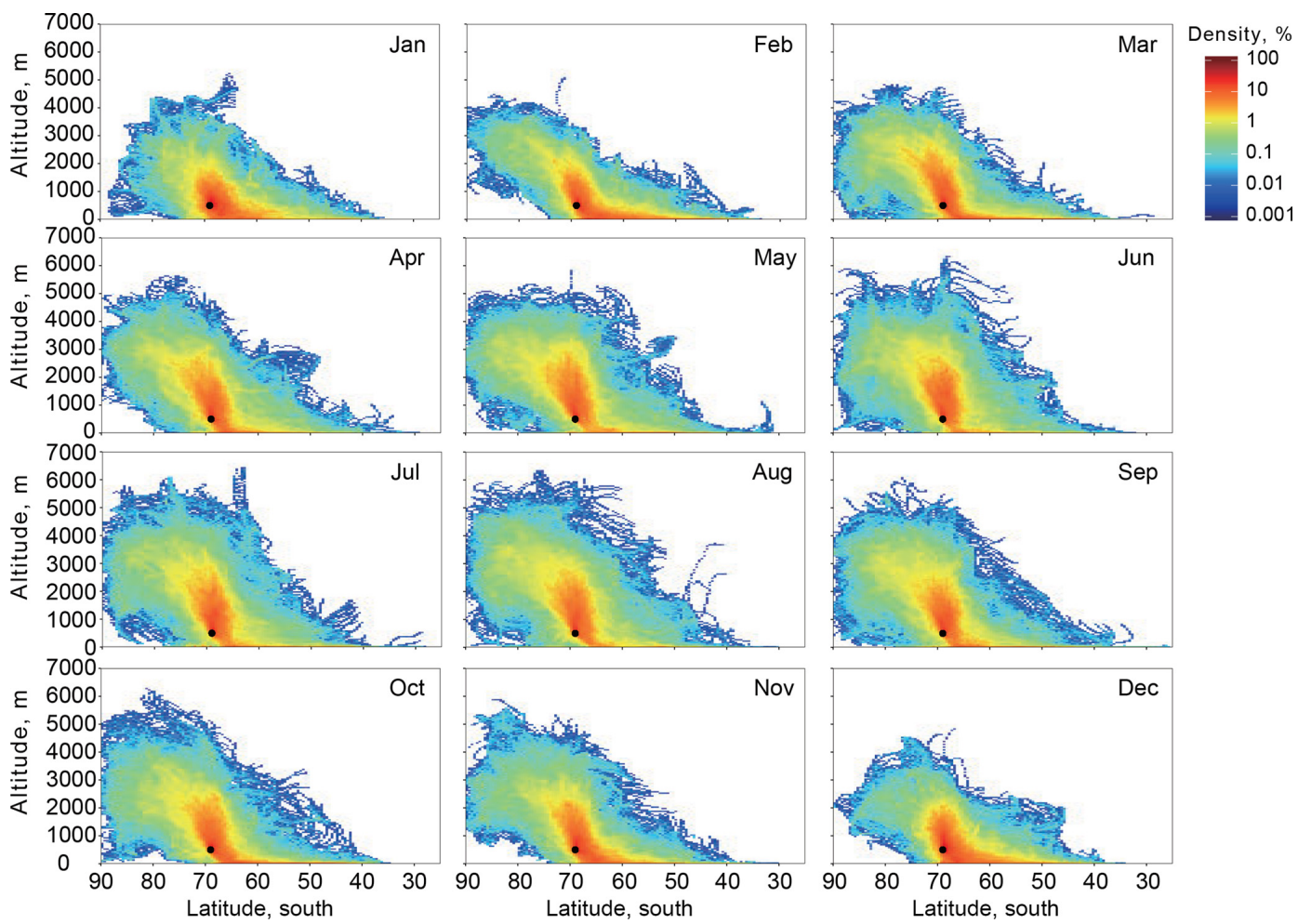

Figure 5. Density plots of vertical motion of air masses transported to Syowa Station in each month. Black points show initial points of the trajectory analysis over Syowa Station. Altitudes are given "above ground level".

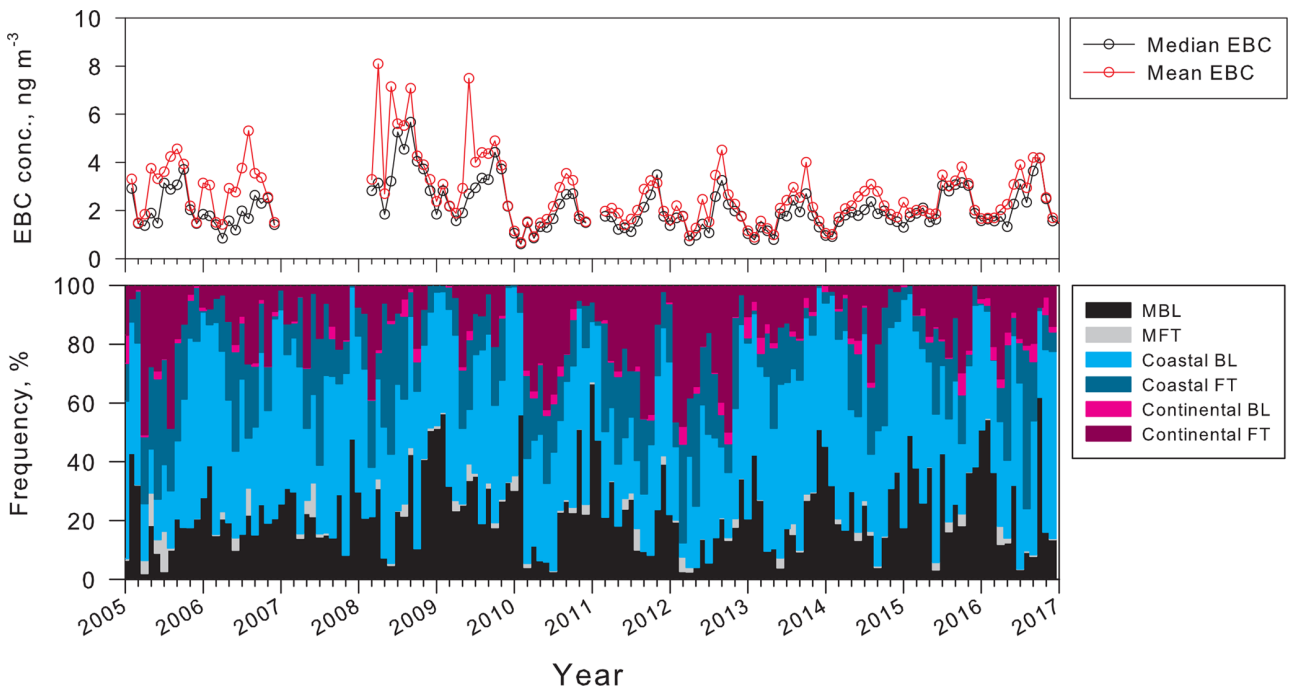

Figure 6. Seasonal features of monthly mean and median EBC concentrations, and air mass origins at Syowa Station. MBL, MFT, coastal $\mathrm{BL}$, coastal FT, continental BL, and continental FT respectively denote the marine boundary layer, marine free troposphere, coastal boundary layer, coastal free troposphere, continental boundary layer, and continental free troposphere.

in other PSAs such as South America. Seasonal variations in CO concentrations and fire counts (Gros et al., 1999; Edwards et al., 2006a, b) were similar to the seasonal features of EBC concentrations at Syowa, as described above. Considering the highest EBC concentrations in MBL, transport via MBL from PSA with biomass burning contributed significantly to EBC concentrations on the Antarctic coasts. Similarly to CO outflow from the continents (Gros et al., 1999; Edwards et al., 2006a, b), EBC outflowed from the PSA. It was subsequently transported to Antarctica, involved with 

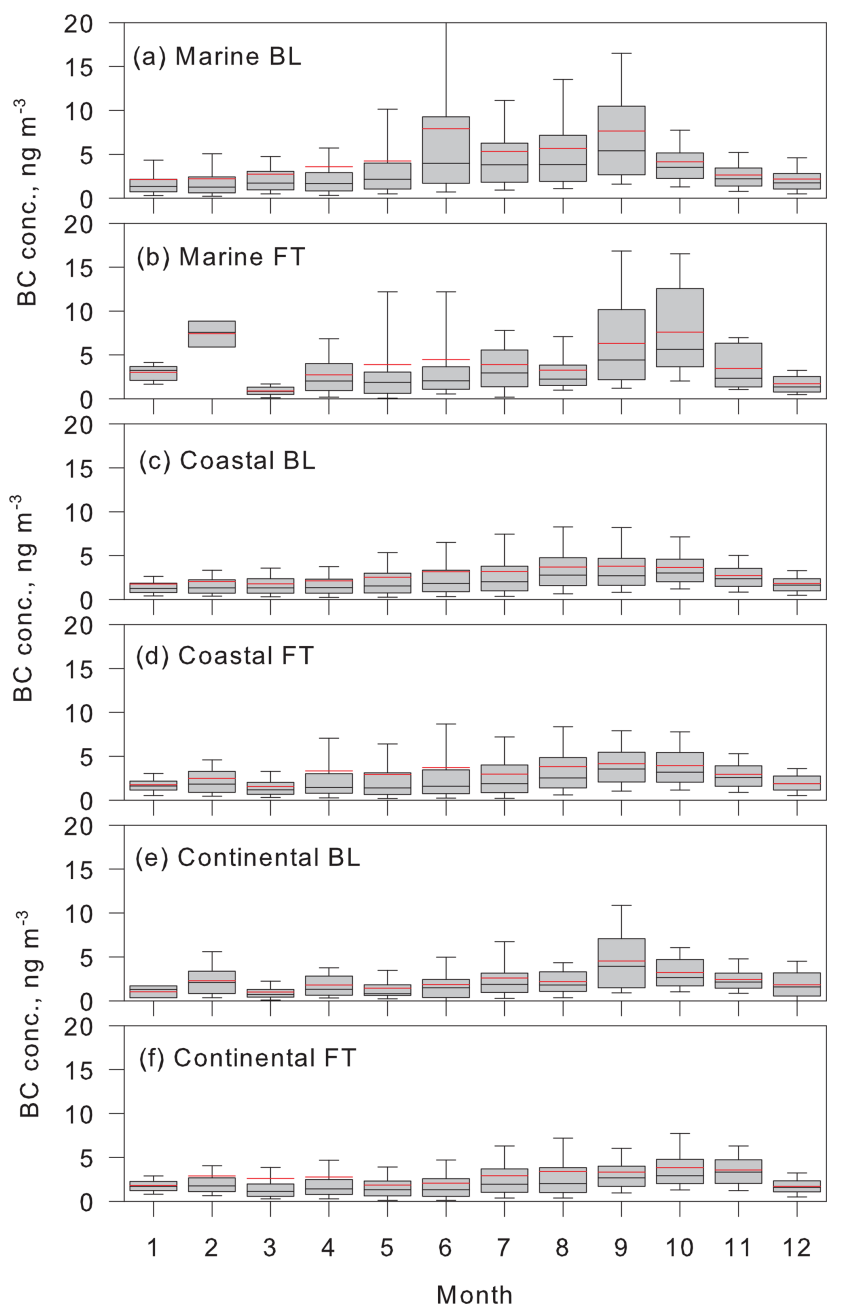

Figure 7. Seasonal features of hourly mean EBC concentrations in each air mass origin at Syowa Station. MBL, MFT, coastal BL, coastal FT, continental BL, and continental FT respectively denote the marine boundary layer, marine free troposphere, coastal boundary layer, coastal free troposphere, continental boundary layer, and continental free troposphere. In box plots, the upper bar, upper box line, black middle box line, bottom box line, and bottom bar respectively denote values of $90 \%, 75 \%, 50 \%$ (median), $25 \%$, and $10 \%$. The red line represents mean values.

cyclone activity in the Southern Ocean (Fiebig et al., 2009; Hara et al., 2010). The end points of the backward trajectory were distributed in the lower troposphere in the marine sector $\left(<66^{\circ} \mathrm{S}\right)$, as depicted in Fig. 5. Therefore, EBC transport to the Antarctic coasts via the free troposphere might occur at altitudes lower than $3000 \mathrm{~m}$.

In spite of lower EBC concentrations in the continental FT, seasonal features of EBC concentrations reached a maximum in October-November in the continental FT (Fig. 7f), in contrast to decreased EBC concentrations in MBL and MFT from November. Additionally, the EBC concentrations from the continental FT were higher than the EBC concentrations measured at the South Pole (Hansen et al., 1988; Wolff and Cachier, 1998). Similar to the latitudinal gradient, the difference in EBC concentrations is expected to be related to the vertical gradient of EBC concentrations over the Antarctic plateau. Indeed, Schwarz et al. (2013) reported higher EBC concentrations in the upper free troposphere than in the lower troposphere over the Antarctic coasts. This fact implies that EBC was supplied to the Antarctic region also via the upper free troposphere. Figure 6 shows that no direct flow from the upper free troposphere over the marine sector to Syowa was identified. Therefore, EBC on the Antarctic coasts might be supplied also by transport via the upper free troposphere from mid-latitudes with subsequent downward flow from the continental FT. Considering the EBC concentrations in the continental FT, EBC transport via the upper FT might make a small contribution to EBC concentrations at Syowa.

\subsection{Origins and potential source areas of $\mathrm{EBC}$ in the Antarctic coast (Syowa)}

Trajectory analysis can provide important information about the relation between EBC concentrations and air mass history, but it cannot let us know the origins and PSA of EBC measured at Syowa (Antarctic coasts). To elucidate the BC origins and PSA, we can compare the EBC data to EBC concentrations simulated using the CHASER model. Figure 8 presents seasonal features of monthly median EBC concentrations measured at Syowa and the model-simulated BC (mBC) concentrations. The $\mathrm{mBC}$ concentrations tended to be lower than the $\mathrm{EBC}$ concentrations in the summer, although the $\mathrm{mBC}$ concentrations were higher during the spring maximum. This difference might result from positive bias using filter-based $\mathrm{BC}$ measurement techniques such as the use of an Aethalometer (e.g. Bond et al., 2013) and uncertainty of EBC transport strength to the Antarctic region involved with aging and deposition processes in the model simulation. Furthermore, the range of the $\mathrm{mBC}$ concentrations and their seasonal features were consistent with those of the observed data (median EBC concentrations): $[\mathrm{mBC}]=0.935 \times[\mathrm{EBC}]_{\text {observed }^{-}}$ $0.0588(R=0.5771)$. Therefore, we discuss EBC origins and PSA using the model data presented below.

In this study, the following EBC origins were classified: (1) biomass burning (BB) such as forest and savanna fires, (2) fossil fuel combustion (FFC), and (3) other combustion (OC). Because "other combustion" includes combustion of biomaterials (e.g. wood fuels), most of the other combustion data were those from the combustion of biomass in a broad sense. Contributions of potential EBC origins showed clear seasonal features as presented in Fig. 9a. Biomass burning was dominant (50\%-80\%, mean $70.7 \%$ ) in the spring EBC maximum at Syowa. By contrast, the FFC contribution was lower (10\%-20\%, mean $14.8 \%)$ than the BB contribution. As described above, earlier results of studies have shown that EBC in the Antarctic troposphere was supplied by BB in the Southern Hemisphere and long-range transport (Wolff and 

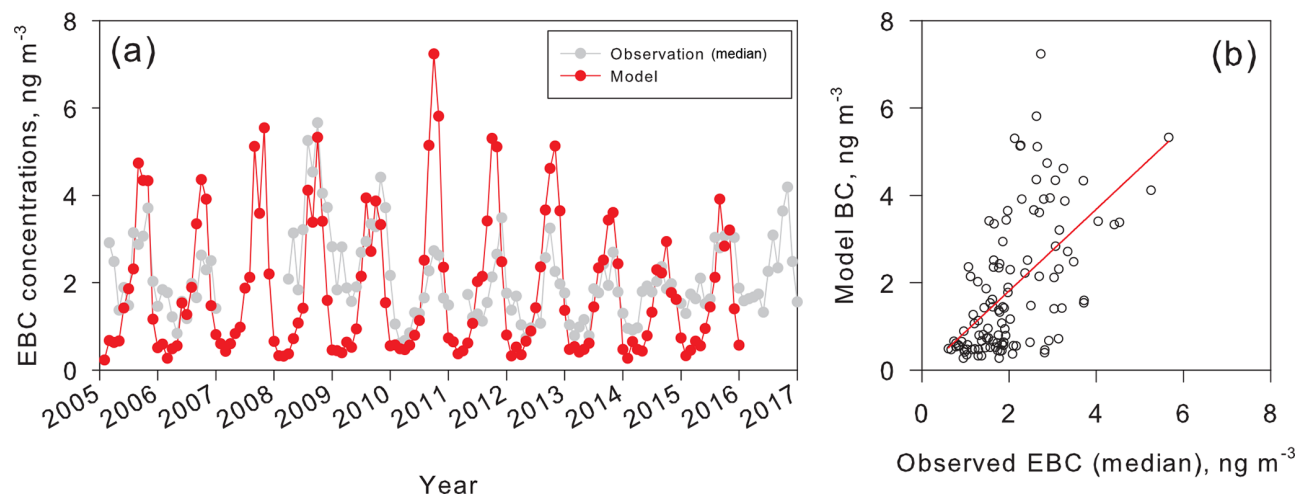

Figure 8. (a) Seasonal features of monthly median EBC concentrations and mBC concentrations at Syowa Station and (b) the relation between monthly median $\mathrm{EBC}$ concentrations and $\mathrm{mBC}$ concentrations. The red line in (b) shows the regression line.

Cachier, 1998; Fiebig et al., 2009; Hara et al., 2010; Weller et al., 2013). Although the OC contribution increased to more than $50 \%$ in autumn-winter (February-June), the periods corresponded to the lower EBC concentrations at Syowa.

Figure $9 \mathrm{~b}$ shows that the $\mathrm{BB} \mathrm{mBC}$ concentrations reached their maximum values at Syowa during August-October, although high $\mathrm{BB} \mathrm{mBC}$ concentrations were found occasionally in July and November. South America, southern Africa, and Australia were identified as the important PSAs of BC at Syowa (Fig. S5). In particular, BB from South America and southern Africa contributed more than $90 \%$ of BB $\mathrm{mBC}$ in the spring maximum (Fig. S4). The contributions of BB in South America and southern Africa in AugustNovember were, respectively, $18.1 \%-62.3 \%$ (mean $42.1 \%$ ) and $15.9 \%-71.7 \%$ (mean $43.3 \%$ ). The relative importance of BB in South America and southern Africa showed a slight year-to-year difference. Moreover, BB mBC concentrations in southern Africa increased more often in earlier months than they did in South America. The BB mBC concentrations in Australia increased in November (after the spring maximum) at Syowa. Contributions and concentrations of BB $\mathrm{mBC}$ in Australia increased drastically after the spring maximum (October-November). However, BB mBC concentrations in Australia were considerably lower at Syowa than those in southern Africa and South America. These differences of seasonal features of $\mathrm{BB} \mathrm{mBC}$ concentrations and their contribution at Syowa in each PSA might be associated with (1) the seasonality of occurrence of BB in each PSA and (2) transport strength from each PSA to Syowa. Indeed, earlier works showed similar seasonal features of fire counts, burned areas, and $\mathrm{CO}$ concentrations and emissions in and over South America, southern Africa, and Australia (Edwards et al., 2006a, b; van der Werf et al., 2006; Giglio et al., 2013). Furthermore, seasonal features of fire counts and aerosol absorption optical depth measured by satellite (OMI) showed a 1-month lag in the maximum of aerosol absorption optical depth (September for Africa and October for South America; Torres et al., 2010). In addition, mineral dust and atmospheric substances from biomass burning can outflow eastwardly from the continents (Edwards et al., 2006a; Fiebig et al., 2009; Hara et al., 2010; Neff and Bertler, 2015). The eastward flow patterns in the Southern Hemisphere are presented in Fig. 4, suggesting strongly that $\mathrm{BB} \mathrm{mBC}$ from southern Africa and South America can be transported directly to Syowa, but rarely from Australia. Consequently, BB $\mathrm{mBC}$ from Australia might usually have a lower contribution at Syowa.

Model simulation showed high BB mBC concentrations in Australia in the late spring periods of 2011 and 2012. Higher EBC concentrations were observed in November 2011 than in November in other years. We must ascertain the transport pathway from Australia to the Syowa to understand the high BB mBC concentrations in Australia. As shown by Neff and Bertler (2015), air masses extended from Australia to the Antarctic coasts in the Pacific Ocean sector. For that reason, $\mathrm{BB} \mathrm{mBC}$ originated in Australia can be transported to Syowa, considering the westward flow along the coastline, as described above. Similarly, BB mBC in southern Africa might contribute only slightly to EBC observed at Halley and Neumayer because of rarely directed transport. Therefore, a lag in the spring maximum of EBC concentrations among Syowa, Halley, and Neumayer might be attributed to the seasonality of BB phenomena in each PSA and the transport strength from PSA to each station.

The BB mBC concentrations at Syowa started increasing in June (Fig. 9b). They increased considerably in August. The EBC concentrations increased gradually after MayJune. In contrast to BB $\mathrm{mBC}$, the concentrations of FFC $\mathrm{mBC}$ and OC-mBC started increasing in May-June (Fig. 9c). Furthermore, good correlation was found between the concentrations of FFC $\mathrm{mBC}$ and OC-mBC $\left(R^{2}=0.9675\right)$, with lower correlation between $\mathrm{BB} \mathrm{mBC}$ and $\mathrm{FFC} \mathrm{mBC}\left(R^{2}=\right.$ $0.4175)$ and between $\mathrm{BB} \mathrm{mBC}$ and $\mathrm{OC}-\mathrm{mBC}\left(R^{2}=0.3654\right)$. The good correlation found between FFC $\mathrm{mBC}$ and OC$\mathrm{mBC}$ implies strongly that seasonal features of FFC mBC 


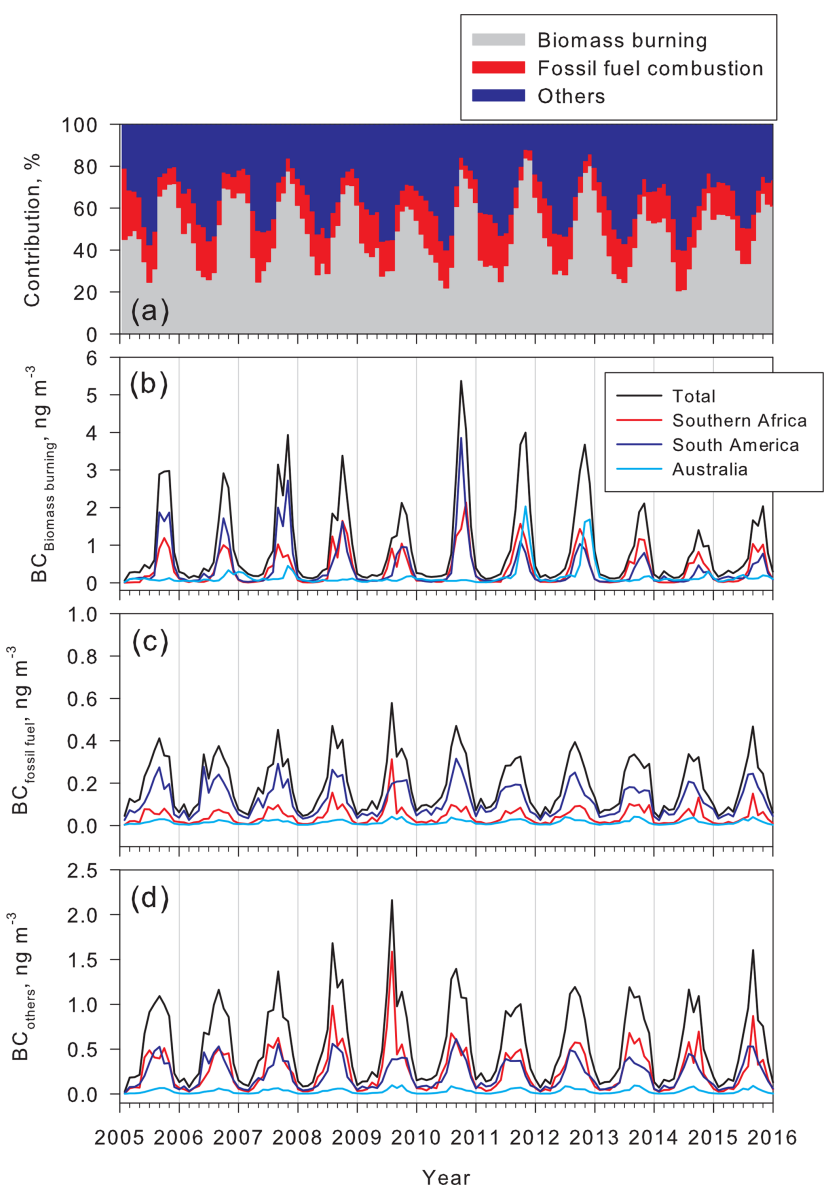

Figure 9. Seasonal features of (a) contribution of potential origins of $\mathrm{mBC}$ at Syowa Station, (b) the concentrations of $\mathrm{mBC}$ released from biomass burning in major PSA, (c) the concentrations of $\mathrm{mBC}$ released from combustion of fossil fuels in major PSA, and (d) the concentrations of $\mathrm{mBC}$ released from the others in major PSA.

and OC-mBC might reflect variations in transport strength from each PSA to Syowa.

South America was found to be the most-contributing PSA (34.1\%-82.4\%; mean, 63.6\%) in FFC mBC at Syowa through the year (Figs. 9c, S5). The FFC mBC contribution in southern Africa was 7.4\%-54.0\% (mean, 20.9\%). In spite of the larger BB contribution in Australia, FFC had a contribution of only $3.9 \%-17.5 \%$ (mean, $8.0 \%$ ), which was lower than that of $\mathrm{BB} \mathrm{mBC}$ in Australia. The contributions of FFC and OC differed greatly from those of BB, especially in South America and southern Africa. The relevant likelihoods must be discussed to elucidate this difference: (1) a difference in the transport pathway of anthropogenic EBC from South America and southern Africa to the Antarctic and (2) differences in EBC emissions from anthropogenic combustion (i.e. fossil fuel use) in South America and southern Africa. Because of eastward cyclone movement in the Southern Ocean, air masses outflowed eastwardly from the continents of South America and southern Africa.
Unlike the African continent, the South American continent extends to $\mathrm{ca} .55^{\circ} \mathrm{S}$. This geographical difference can engender higher contributions of anthropogenic EBC emitted from South America. Indeed, direct evidence of EBC transport from South America was reported in earlier works (Pereira et al., 2006; Fiebig et al., 2009; Hara et al., 2010). In addition, higher contributions from South America were observed in transport of mineral dusts to the Antarctic (e.g. Delmonte et al., 2004, 2008; Gassó et al., 2010; Li et al., 2010). Considering that both $\mathrm{BB} \mathrm{mBC}$ and $\mathrm{FFC} \mathrm{mBC}$ outflowed simultaneously from each PSA, the transport processes cannot account for the difference between contributions of $\mathrm{BB} \mathrm{mBC}$ and FFC mBC. Unlike FFC, BB has strong seasonality in each PSA as described above. Furthermore, fossil fuel consumption depends on the gross domestic product (GDP). Indeed, the aggregated GDPs of countries in South America are the largest in the Southern Hemisphere. Therefore, the difference in FFC mBC contribution might reflect the fossil fuel consumption related to population and economic activity in the respective PSAs. Because of rapid population expansion in the countries of southern Africa recently, it is expected that more EBC can be released by fossil fuel combustion in southern Africa in the future. Therefore, continual EBC measurements must be conducted at the Antarctic coasts to monitor the atmospheric substances (e.g. EBC) originating from combustion in the Southern Hemisphere.

The concentrations of BB $\mathrm{mBC}$, FFC $\mathrm{mBC}$, and $\mathrm{OC}-\mathrm{mBC}$ showed minima during February-April/May, although poleward flow via MBL and MFT occurred as portrayed in Fig. 6. The following possibilities are contributing factors: seasonal features of (1) EBC source strength in each PSA and (2) air mass history (i.e. air mass origins). As demonstrated by earlier work (Edwards et al., 2006a, b; van den Werf et al., 2006; Torres et al., 2010), EBC emissions from BB in South America, southern Africa, and Australia showed strong seasonal variation, with lower fire counts in February-April/May because of the large precipitation amounts. In the CHASER model, fresh BC immediately after release from BB is assumed to be hydrophobic, so that very little fresh $B C$ might be removed by precipitation near source areas. Aging processes during transport can engender gradual change into internal mixtures of $\mathrm{BC}$ with a hydrophilic surface. Then, $\mathrm{BC}$ can be scavenged through wet deposition during transport. Considering clear seasonal features of $\mathrm{CO}$ with longer residence time than BC (Edwards et al., 2006a, b; van den Werf et al., 2006), seasonal variation in $\mathrm{BC}$ emissions might have a greater contribution to seasonal features of $\mathrm{mBC}$ and $\mathrm{EBC}$ at Syowa than wet deposition of $\mathrm{BC}$ during transport.

Results show that $\mathrm{BB}$ was the greatest factor affecting EBC concentrations in the Southern Hemisphere. Therefore, the seasonal features of biomass burning might affect EBC concentrations in the Antarctic region. However, it is noteworthy that FFC mBC concentrations also showed a minimum in February-April/May at Syowa. This fact cannot be explained by the seasonal features of BB. Assuming that FFC 
$\mathrm{mBC}$ is useful as a proxy for transport from the continents with human activity to the Antarctic region, the EBC minimum in February-April/May might be associated not only with the features of $\mathrm{BB}$, but also with the features of the air mass history. As portrayed in Fig. 6, the contributions of air masses identified as coastal BL and continental FT increased in February-April/May in the most years, and particularly in 2010. A similar tendency (high contribution of the upper atmosphere at surface of Antarctic coasts in austral autumn) was also identified from FLEXPART analysis by Stohl and Sodemann (2010). The EBC source strength in the Antarctic region, especially in FT over the Antarctic continent, is lower or negligible. Therefore, the seasonal features of BB in the Southern Hemisphere and air mass origins at Syowa might engender the EBC minimum at Syowa.

\subsection{Variations in AAE at Syowa Station, Antarctica}

In addition to seasonal features of EBC concentrations (Fig. 3), AAE showed clear seasonal variation at Syowa (Fig. 10). AAE ranged mostly by $0.5-1.0$ in April-October and 1.0-1.5 in summer (December-February) during our measurement at Syowa. AAE increased slightly in the maximum of EBC concentrations (September-October). Earlier works confirmed $\mathrm{AAE}=1$ in the case of dominance of external mixed EBC (e.g. Bond et al., 2013; references therein). By contrast, AAE of the coated BC (i.e. internal mixed EBC) is lower than 1 (Leck and Cappa, 2010; Bond et al., 2013). Aethalometer measurements cannot provide direct information related to the mixing states of carbonaceous aerosols. As suggested by Fiebig et al. (2009) and Hara et al. (2010), EBC is expected to be transported from mid-latitudes and low latitudes. Therefore, EBC mixing states might be changed by aging processes near source regions and during long-range transport (Shiraiwa et al., 2007; Saleh et al., 2013, 2014; Ueda et al., 2018). Indeed, Ueda et al. (2018) showed that EBC was present mostly as internal mixtures in the marine boundary layer (MBL) of the Southern Ocean. The CHASER model also indicates that internal mixing states of $\mathrm{BC}$ were dominated through the year (not shown, details published elsewhere). Therefore, lower AAE in April-October might result from the dominant presence of coated EBC particles (internal mixtures) at Syowa. The slight AAE increase corresponded to the spring maximum of EBC concentrations. The following possibilities were considered for the slight AAE increase: (1) a change in the mixing states of $\mathrm{BC}$ and (2) a contribution of other light-absorbing materials such as organic aerosols and minerals. The organic aerosols and minerals have high AAE, for instance 3.5-7 for organics and typically 2-3 for minerals (e.g. Bond et al., 2013, and references therein). Although the internal mixing states of $\mathrm{BC}$ were dominant in CHASER model simulation, external mixtures of $\mathrm{BC}$ increased in the spring EBC maximum (not shown, details will be published elsewhere). Considering the AAE of external mixing of $\mathrm{BC}$, an increase in external mixing of $\mathrm{BC}$ can engender an AAE increase. Additionally, the spring EBC maximum at the Antarctic coasts was associated closely with biomass burning. Organic aerosols with high AAE derived from biomass burning were expected to be transported simultaneously into Antarctica. Consequently, transport of organic aerosols might contribute to the slight AAE increase in September-October. By contrast, high AAE in summer cannot be explained solely by EBC aging processes. Earlier results of studies have shown high concentrations of mineral particles $(\mathrm{Al})$ at Neumayer in the summer (Wagenbach, 1996; Weller et al., 2013). Therefore, it is necessary to assess the effects of organic aerosols and mineral particles on optical absorption during summer.

Considering strong optical absorption by organics (i.e. $\mathrm{BrC}$ ) in the UV range, the contribution of organics can be assessed from comparison between AAE in UV-IR channels (AAE $\mathrm{UV}_{-\mathrm{IR}}, \lambda=370-950 \mathrm{~nm}$ ) and AAE in Vis-IR channels (AAE $\mathrm{Vis}_{\mathrm{V}-\mathrm{IR}}, \lambda=590-950 \mathrm{~nm}$ ). Figure 11 depicts the relation between $\mathrm{AAE}_{\mathrm{UV}-\mathrm{IR}}$ and $\mathrm{AAE} \mathrm{E}_{\mathrm{Vis}-\mathrm{IR}}$. The correlation between $\mathrm{AAE}_{\mathrm{UV}-\mathrm{IR}}$ and $\mathrm{AAE}_{\mathrm{Vis}-\mathrm{IR}}$ was observed throughout the year. In particular, high correlation $\left(R^{2}>0.7\right)$ was obtained in March and September-December. Monthly median ratios of $\mathrm{AAE}_{\mathrm{Vis}-\mathrm{IR}} / \mathrm{AAE}_{\mathrm{UV}-\mathrm{IR}}$ were $0.55-0.92$ (Fig. 11b). In particular, higher ratios $(0.88-0.92)$ were found in the spring maximum of the EBC concentration (SeptemberNovember). High optical absorption by organic aerosols in the UV ranges engenders an increase in $\mathrm{AAE}_{\mathrm{UV}-\mathrm{IR}}$ and the higher ratios (e.g. Bond et al., 2013). Therefore, the difference suggests that organic aerosols, rather than effects of mineral particles, contributed to optical absorption and AAE. The results of linear regression, as portrayed in Fig. 11, indicated that intercepts had negative values in all months. In particular, larger negative intercept values $(\leq-0.4)$ were obtained for October-November (Fig. 11d). Considering that $\mathrm{EBC}$ in the EBC maximum might be associated with biomass burning and long-range transport (details discussed in later sections), it is expected that large amounts of biomassburning-origin organic aerosols are transported to Antarctica. Indeed, the concentrations of particulate oxalate show a spring maximum (Fig. S6). Additionally, high concentrations of oxalate and brown carbons are associated with secondary organic aerosol formation in a condensed phase (e.g. Zhang et al., 2012). When optical absorption in UV regions was increased by organic aerosols (i.e. BrC), correlation between $\mathrm{AAE}_{\mathrm{UV}-\mathrm{IR}}$ and $\mathrm{AAE} \mathrm{E}_{\mathrm{Vis}-\mathrm{IR}}$ can be shifted to a larger AAE ${ }_{U V-I R}$ region. This change might engender larger negative intercept values. Therefore, the larger negative intercepts in October-November might result from the effects of organic aerosols derived from biomass burning.

Considering that EBC concentrations decreased in summer (December-February) at Syowa, organic aerosols and their precursors might be supplied not from combustion processes but from the other sources. One major organic aerosol constituent was found to be $\mathrm{CH}_{3} \mathrm{SO}_{3}^{-}$(Fig. S6), which is involved with oceanic bioactivity and photochemical processes 

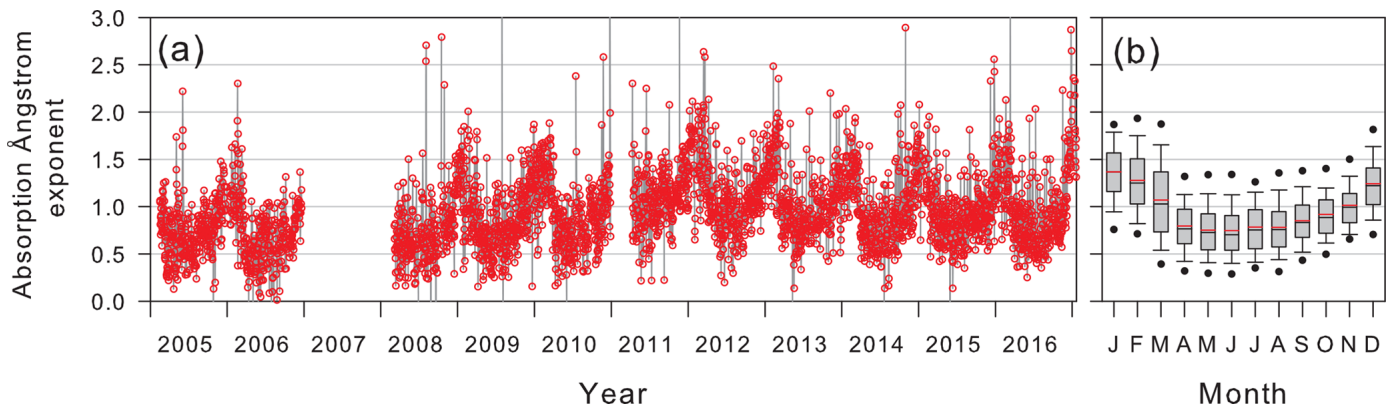

Figure 10. Seasonal features of (a) daily median AAE $(\lambda=370-950 \mathrm{~nm})$ and (b) monthly box plot of AAE at Syowa since February 2005 . AAE data were not available in January 2007-January 2008 and January 2011-early April 2011 because of mechanical troubles with the Aethalometer. In box plots, the upper bar, upper box line, black middle box line, bottom box line, and bottom bar respectively denote values of $90 \%, 75 \%, 50 \%$ (median), $25 \%$, and $10 \%$. The red line shows mean values.

(a) Relation between $A A E_{U V-I R}$ and $A A E_{V i s-I R}$
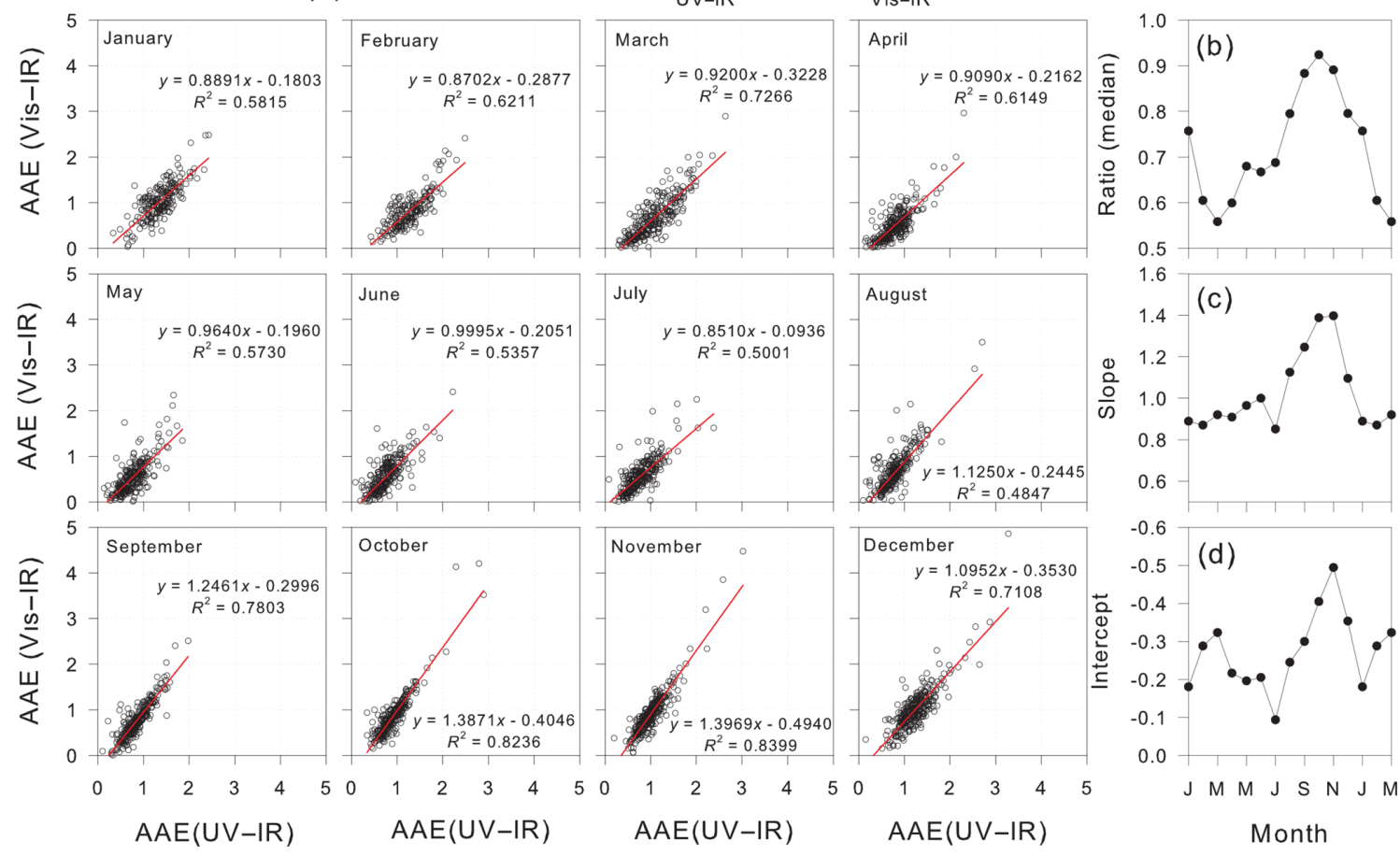

Figure 11. (a) Relations between absorption Angstrom exponent (AAE) in UV-IR channels and AAE in Vis-IR channels, and seasonal features of (b) ratios of $\mathrm{AAE}_{\mathrm{Vis}-\mathrm{IR}} / \mathrm{AAE}_{\mathrm{UV} / \mathrm{IR}}$ and (c) slope and (d) intercepts in the linear regression lines. AAE data with $\mathrm{BC}$ concentrations lower than $0.2 \mathrm{ng} \mathrm{m}^{-3}$ (detection limit) were excluded from the plots. Red lines represent regression lines.

on the Antarctic coasts during summer (e.g. Minikin et al., 1998; Preunkert et al., 2008). Indeed, $\mathrm{CH}_{3} \mathrm{SO}_{3}^{-}$was identified as an internal mixture with $\mathrm{SO}_{4}^{2}-$ in the Antarctic coasts (Hara et al., 1996). In addition, aerosol particles containing $\mathrm{SO}_{4}^{2}$ - were present as strong acidic droplets in the Antarctic troposphere (e.g. Hara et al., 2013, references therein). Therefore, $\mathrm{CH}_{3} \mathrm{SO}_{3}^{-}$might be present as an acidic solution in aerosols in the Antarctic troposphere during summer. $\mathrm{CH}_{3} \mathrm{SO}_{3} \mathrm{H}$ aqueous solutions have strong optical absorption in the UV range (Fig. S7). Indeed, the imaginary refractive index has a weak band in the UV region (Myhre et al., 2004).
Therefore, AAE in the summer (December-February) might be associated with $\mathrm{EBC}$ aging processes and with the presence and mixing of organic aerosols (e.g. $\left.\mathrm{CH}_{3} \mathrm{SO}_{3} \mathrm{H}\right)$ derived from oceanic bioactivity.

In contrast to the AAE summer maximum, AAE increased slightly in the spring EBC maximum (Fig. 10). Moreover, slopes showing the relation of $\mathrm{AAE}_{\mathrm{UV}-\mathrm{IR}}$ to $\mathrm{AAE}_{\mathrm{Vis}-\mathrm{IR}}$ in the linear regressions during the EBC maximum exhibited maximum (slopes $\geq 1$ ) at Syowa, as portrayed in Fig. 11. The concentrations of EBC and organic aerosols derived from biomass burning increased in the spring maximum as de- 
scribed above, whereas the EBC concentrations decreased and the concentrations of organic aerosols such as $\mathrm{CH}_{3} \mathrm{SO}_{3}^{-}$ derived from oceanic bioactivity increased during summer. In addition, the optical absorption of $\mathrm{BrC}$ was found to vary greatly depending on the origins of $\mathrm{BrC}$ (Moschos et al., 2018). Therefore, these differences might engender seasonal features of aerosol optical absorption properties related to the concentrations of EBC and organic aerosols, optical absorption properties of $\mathrm{BrC}$, and mixing states of aerosol constituents at Syowa.

\section{Conclusions}

EBC measurements have been conducted at Syowa Station, Antarctica, since February 2005. Long-term trends over approximately a decade were almost constant in 2005-2016. Seasonal features of EBC concentrations at Syowa showed maximum values in September-October and minimum values in February-April, similar to the seasonal features observed at Neumayer, Halley, and the South Pole (Wolff and Cachier, 1998; Weller et al., 2013). Comparison between EBC concentrations and air mass origins identified by backward trajectory implies that EBC on the Antarctic coasts was supplied mostly by transport via the MBL and lower free troposphere, particularly during winter-spring. Additionally, some EBC was due to the burden on Antarctica through the upper troposphere; it was then transported downward from the continental free troposphere to near the surface at Syowa. The EBC minimum might be attributable to general transport patterns (higher contributions of the free troposphere and coastal boundary layer). The CHASER model simulation showed that the most important origins and PSA of EBC at Syowa Station were biomass burning in South America and southern Africa. Fossil fuel combustion in South America and southern Africa also have important contributions. South America is the most important PSA of mBC derived from fossil fuel combustion. Aerosol optical properties based on AAE showed clear seasonal features of AAE, with 0.5-1.0 during April-October and a maximum (1.0-1.5) in December-February. The AAE features might be associated with organic aerosols and mixing states of EBC. With population growth and economic development in the Southern Hemisphere, more anthropogenic BC is expected to be released in the future. Moreover, the PSA of EBC is apparently different between Neumayer in the Atlantic Ocean sector and Syowa in the Indian Ocean sector. Therefore, continual EBC measurements must be taken at Syowa Station to elucidate the EBC burden into the Antarctic region and effects on surface albedo and atmospheric aerosol absorbing in the future. Furthermore, these data can provide a better understanding and interpretation of EBC records in Antarctic ice cores from the perspectives of transport processes and the biomass burning history.
Data availability. Data are available upon request from the corresponding author (harakei@fukuoka-u.ac.jp). 


\section{Appendix A: List of acronyms used in this study}

$\begin{array}{ll}\text { AAE } & \text { Absorption Ångström exponent } \\ \text { AAE }_{\mathrm{UV}-\mathrm{IR}} & \text { Absorption Angström exponent in range of UV-IR }(\lambda=370-950 \mathrm{~nm}) \\ \text { AAE }_{\text {Vis-IR }} & \text { Absorption Angström exponent in range of Vis-IR }(\lambda=590-950 \mathrm{~nm}) \\ \text { BB } & \text { Biomass burning } \\ \text { BC } & \text { Black carbon } \\ \text { BL } & \text { Boundary layer } \\ \text { BrC } & \text { Brown carbon } \\ C_{\text {abs }} & \text { Optical absorption cross section } \\ \text { CCM } & \text { Chemistry climate model } \\ \text { CHASER } & \text { Chemical atmospheric global climate model for studies of atmospheric environment and } \\ & \text { radiative forcing } \\ \text { EBC } & \text { Equivalent black carbon. In this study, we use the term EBC for the corrected mass BC } \\ & \text { concentrations and the measured BC concentrations using filter-based optical techniques } \\ & \text { in previous works. } \\ \text { EC } & \text { Elemental carbon } \\ \text { ENSO } & \text { El Niño-Southern Oscillation } \\ \text { ESM } & \text { Earth system model } \\ \text { FFC } & \text { Fossil fuel combustion } \\ \text { FT } & \text { Free troposphere } \\ \text { GDP } & \text { Gross domestic product } \\ \text { HYSPLIT } & \text { Hybrid Single-Particle Lagrangian Integrated Trajectory model } \\ \text { IR } & \text { Infrared } \\ \text { JARE } & \text { Japanese Antarctic research expedition } \\ \text { LFT } & \text { Lower free troposphere } \\ \text { MAAP } & \text { Multi-angle absorption photometer } \\ \text { mBC } & \text { Model BC (estimated using the CHASER model }) \\ \text { MBL } & \text { Marine boundary layer } \\ \text { MFT } & \text { Marine free troposphere } \\ \text { MIROC } & \text { Model for Interdisciplinary Research On Climate } \\ \text { NMVOCs } & \text { Non-methane volatile organic carbons } \\ \text { OC } & \text { Other combustion } \\ \text { PSA } & \text { Potential source area } \\ \text { PSAP } & \text { Particulate soot absorption photometer } \\ \text { rBC } & \text { Refractory BC } \\ \text { SP2 } & \text { Single-particle soot photometer } \\ \text { SPRINTARS } & \text { Spectral Radiation-Transport Model for Aerosol Species } \\ \text { UV } & \text { Ultraviolet } \\ \text { Vis } & \text { Visible } \\ & \end{array}$


Supplement. The supplement related to this article is available online at: https://doi.org/10.5194/acp-19-7817-2019-supplement.

Author contributions. KH, KO, MS, and TY designed the experiments, which were conducted by $\mathrm{KO}, \mathrm{KH}$, and $\mathrm{MY}$. KH wrote the manuscript and analysed $\mathrm{BC}$ data and backward trajectory. $\mathrm{KH}$ and MY analysed and discussed aerosol optical properties. KS and TO developed and conducted the tagged $\mathrm{BC}$ simulation using the CHASER model. All authors reviewed and commented on the paper.

Competing interests. The authors declare that they have no conflict of interest.

Acknowledgements. We would like to thank Yuichi Aoyama, Yasuo Takeda, Takuya Masunaga, Takeshi Kinase, Chusaku Ikeda, Yikiko Hayakawa, Jyunji Matsushita, and Itsuto Arakawa for help with aerosol measurements at Syowa Station, Antarctica, and C. NishitaHara for measurement of the absorbance of the MSA aqueous solution. We obtained MACC reanalysis data from the European Centre for Medium-Range Weather Forecasts (ECMWF). This study was supported by the "Observation project of global atmospheric change in the Antarctic" for JARE 43-47, and Grants-in-Aid for Scientific Research (B) (no. 22310013 and 15H02806, PI: K. Hara) from the Ministry of Education, Culture, Sports, Science and Technology of Japan.

Financial support. This study is a part of the Science Program of the Japanese Antarctic Research Expedition (JARE). It was supported by the National Institute of Polar Research (NIPR) under MEXT. This research has been supported by the JSPS Grantsin-Aid for Scientific Research (B) (grant no. 22310013) 25 and the JSPS Grants-in-Aid for Scientific Research (B) (grant no. 15H02806).

Review statement. This paper was edited by Alex Lee and reviewed by two anonymous referees.

\section{References}

Aarons, S. M., Aciego, S. M., Gabrielli, P., Delmonte, B., Koornneef, J. M., Wegner, A., and Blakowski, M. A.: The impact of glacier retreat from the Ross Sea on local climate: Characterization of mineral dust in the Taylor Dome ice core, East Antarctica, Earth Planet. Sci. Lett., 444, 34-44, https://doi.org/10.1016/j.epsl.2016.03.035, 2016.

Albani, S., Mahowald, N., Delmonte, B., Maggi, V., and Winckler, G.: Comparing modeled and observed changes in mineral dust transport and deposition to Antarctica between the Last Glacial Maximum and current climates, Clim. Dynam., 38, 1731-1755, https://doi.org/10.1007/s00382-011-1139-5, 2012.
Andreae, M. O. and Gelencsér, A.: Black carbon or brown carbon? The nature of light-absorbing carbonaceous aerosols, Atmos. Chem. Phys., 6, 3131-3148, https://doi.org/10.5194/acp-63131-2006, 2006.

Aoki, T., Kuchiki, K., Niwano, M., Kodama, Y., Hosaka, M., and Tanaka, T.: Physically based snow albedo model for calculating broadband albedos and the solar heating profile in snowpack for general circulation models, J. Geophys. Res., 116, D11114, https://doi.org/10.1029/2010JD015507, 2011.

Arienzo, M., McConnell, J., Murphy, L., Chellman, N., Das, S., Kipfstuhl, S., and Mulvaney, R.: Holocene black carbon in Antarctica paralleled Southern Hemisphere climate, J. Geophys. Res.-Atmos., 122, 6713-6728, https://doi.org/10.1002/2017JD026599, 2017.

Bisiaux, M. M., Edwards, R., McConnell, J. R., Curran, M. A. J., Van Ommen, T. D., Smith, A. M., Neumann, T. A., Pasteris, D. R., Penner, J. E., and Taylor, K.: Changes in black carbon deposition to Antarctica from two high-resolution ice core records, 1850-2000 AD, Atmos. Chem. Phys., 12, 4107-4115, https://doi.org/10.5194/acp-12-4107-2012, 2012.

Bodhaine, B. A.: Aerosol absorption measurements at Barrow, Mauna Loa and the South Pole, J. Geophys. Res.-Atmos. (19842012), 100, 8967-8975, https://doi.org/10.1029/95JD00513, 1995.

Bond, T. C, Doherty, S. J., Fahey, D. W., Forster, P. M., Berntsen, T., DeAngelo, B. J., Flanner, M. G., Ghan, S., Kärcher, B., Koch, D., Kinne, S., Kondo, Y., Quinn, P. K., Sarofim, M. C., Schultz, M. G., Schulz, M., Venkataraman, C., Zhang, H., Zhang, S., Bellouin, N., Guttikunda, S. K., Hopke, R. K., Jacobson, M. Z., Kaiser, J. W., Klimont, Z., Lohmann, U., Schwarz, J. P., Shindell, D., Storelvmo, T., Warren, S. G., and Zender, C. S.: Bounding the role of black carbon in the climate system: A scientific assessment, J. Geophys. Res.-Atmos., 118, 5380-5552, https://doi.org/10.1002/jgrd.50171, 2013.

Bory, A., Wolff, E., Mulvaney, R., Jagoutz, E., Wegner, A., Ruth, U., and Elderfield, H.: Multiple sources supply eolian mineral dust to the Atlantic sector of coastal Antarctica: Evidence from recent snow layers at the top of Berkner Island ice sheet, Earth Planet. Sci. Lett., 291, 138-148, https://doi.org/10.1016/j.epsl.2010.01.006, 2010.

Chang, C., Han, C., Han, Y., Hur, S., Lee, S., Motoyama, H., Hou, S., and Hong, S.: Persistent Pb pollution in central East Antarctic snow: a retrospective assessment of sources and control policy implications, Environ. Sci. Technol., 50, 12138-12145, https://doi.org/10.1021/acs.est.6b03209, 2016.

Chaubey, J., Moorthy, B., Nair, V., and Tiwari, A.: Black carbon aerosols over coastal Antarctica and its scavenging by snow during the Southern Hemispheric summer, J. Geophys. Res., 115, D10210, https://doi.org/10.1029/2009JD013381, 2010.

Collaud Coen, M., Weingartner, E., Apituley, A., Ceburnis, D., Fierz-Schmidhauser, R., Flentje, H., Henzing, J. S., Jennings, S. G., Moerman, M., Petzold, A., Schmid, O., and Baltensperger, U.: Minimizing light absorption measurement artifacts of the Aethalometer: evaluation of five correction algorithms, Atmos. Meas. Tech., 3, 457-474, https://doi.org/10.5194/amt-3-4572010, 2010.

De Deckker, P., Norman, M., Goodwin, I., Wain, A., and Gingele, F.: Lead isotopic evidence for an Australian source of aeolian dust to Antarctica at times over the last 170,000 
years, Palaeogeogr. Palaeoclim. Palaeoecol., 285, 205-223, https://doi.org/10.1016/j.palaeo.2009.11.013, 2010.

Delmonte, B., Petit, J. R., Andersen, P. S., Basile-Doelsch, I., Maggi, V., and Lipenkov, V.: Dust size evidence for opposite regional atmospheric circulation changes over east Antarctica during the last climatic transition, Clim. Dynam., 23, 427-438, https://doi.org/10.1007/s00382-004-0450-9, 2004.

Delmonte, B., Andersson, P. S., Hansson, M., Schöberg, H., Petit, J. R., Basile-Doelsch, I., and Maggi, V.: Aeolian dust in East Antarctica (EPICA-Dome C and Vostok): Provenance during glacial ages over the last $800 \mathrm{kyr}$, Geophys. Res. Lett., 35, L07703, https://doi.org/10.1029/2008GL033382, 2008.

Edwards, D. P., Emmons, L. K., Gille, J. C., Chu, A., Attié, J.-L., Giglio, L., Wood, S. W., Haywood, J., Deeter, M. N., Massie, S. T., Ziskin, D. C., and Drummond, J. R.: Satellite-observed pollution from Southern Hemisphere biomass burning, J. Geophys. Res., 111, D14312, https://doi.org/10.1029/2005JD006655, 2006a.

Edwards, D. P., Pétron, G., Novelli, P., Emmons, L., Gille, J. C., and Drummond, J. R.: Southern Hemisphere carbon monoxide interannual variability observed by Terra/Measurement of Pollution in the Troposphere (MOPITT), J. Geophys. Res., 111, D16303, https://doi.org/10.1029/2006JD007079, 2006b.

Evangelista, H., Maldonado, J., Godoi, R. H. M.,, Pereira, E. B., Koch, D., Tanizaki-Fonseca, K., Grieken, V., R., Sampaio, M., Setzer, A., Alencar, A., and Gonçalves, S. C.: Sources and transport of urban and biomass burning aerosol black carbon at the South-West Atlantic Coast, J. Atmos. Chem., 56, 225-238, https://doi.org/10.1007/s10874-006-9052-8, 2007.

Fiebig, M., Lunder C. R., and Stohl, A.: Tracing biomass burning aerosol from South America to Troll Research Station, Antarctica, Geophys. Res. Lett., 36, L14815, https://doi.org/10.1029/2009GL038531, 2009.

Flanner, M., Zender, C., Randerson, J., and Rasch, P.: Present-day climate forcing and response from black carbon in snow, J. Geophys. Res., 112, D11202, https://doi.org/10.1029/2006JD008003, 2007.

Gabrielli, P., Wegner, A., Petit, J., Delmonte, B., Deckker, P., Gaspari, V., Fischer, H., Ruth, U., Kriews, M., Boutron, C., Cescon, P., and Barbante, C.: A major glacial-interglacial change in aeolian dust composition inferred from Rare Earth Elements in Antarctic ice, Quaternary Sci. Rev., 29, 265-273, https://doi.org/10.1016/j.quascirev.2009.09.002, 2010.

Gambaro, A., Zangrando, R., Gabrielli, P., Barbante, C., and Cescon, P.: Direct determination of levoglucosan at the picogram per milliliter level in Antarctic ice by highperformance liquid chromatography/electrospray ionization triple quadrupole mass spectrometry, Anal. Chem., 80, 16491655, https://doi.org/10.1021/ac701655x, 2008.

Gassó, S., Stein, A., Marino, F., Castellano, E., Udisti, R., and Ceratto, J.: A combined observational and modeling approach to study modern dust transport from the Patagonia desert to East Antarctica, Atmos. Chem. Phys., 10, 8287-8303, https://doi.org/10.5194/acp-10-8287-2010, 2010.

Gelencsér, A: Chapter 3: Major carbonaceous particle types and their sources in "Carbonaceous aerosol", 45-147, Springer, 2004.

Giglio, L., Randerson, J., and Werf, G.: Analysis of daily, monthly, and annual burned area using the fourth-generation global fire emissions database (GFED4), J. Geophys. Res.-Biogeosci., 118, 317-328, https://doi.org/10.1002/jgrg.20042, 2013.

Gilardoni, S. and Fuzzi, S., Chemical composition of aerosols of different origin in "Atmospheric aerosols: Life cycles and effects on air quality and climate" edited by Tomasi, C., Fuzzi, S., and Kokhanovsky, A., 183-221, Wiley-VCH, 2017.

Gili, S., Gaiero, D., Goldstein, S., Chemale, F., Koester, E., Jweda, J., Vallelonga, P., and Kaplan, M.: Provenance of dust to Antarctica: A lead isotopic perspective, Geophys. Res. Lett., 43, 22912298, https://doi.org/10.1002/2016GL068244, 2016.

Graf, H.-F., Shirsat, S. V., Oppenheimer, C., Jarvis, M. J., Podzun, R., and Jacob, D.: Continental scale Antarctic deposition of sulphur and black carbon from anthropogenic and volcanic sources, Atmos. Chem. Phys., 10, 2457-2465, https://doi.org/10.5194/acp-10-2457-2010, 2010.

Gros, V., Bonsang, B., Martin, D., Novelli, P. C., and Kazan, V.: Carbon monoxide short term measurements at Amsterdam island: estimations of biomass burning emission rates, Chemosphere - Global Change Sci., 1, 163-172, https://doi.org/10.1016/S1465-9972(99)00009-4, 1999.

Hadley, O. and Kirchstetter, T.: Black-carbon reduction of snow albedo, Nat. Clim. Change, 2, 437-440, https://doi.org/10.1038/nclimate1433, 2012.

Hagler, G. S. W., Bergin, M. H., Smith, E. A., Town, M., and Dibb, J. E.: Local anthropogenic impact on particulate elemental carbon concentrations at Summit, Greenland, Atmos. Chem. Phys., 8, 2485-2491, https://doi.org/10.5194/acp-8-2485-2008, 2008.

Hansen, A. D. A., Bodhaine, B. A., Dutton, E. G., and Schnell, R. C.: Aerosol black carbon measurements at the South Pole: Initial results, 1986-1987, Geophys. Res. Lett., 15, 1193-1196, https://doi.org/10.1029/GL015i011p01193, 1988.

Hansen, A., Lowenthal, D., Chow, J., and Watson, J.: Black carbon aerosol at McMurdo station, Antarctica, J. Air Waste Manage. Assoc., 51, 593-600, https://doi.org/10.1080/10473289.2001.10464283, 2001.

Hara, K., Kikuchi, T., Furuya, K., Hayashi, M., and Fujii, Y.: Characterization of Antarctic aerosol particles using laser microprobe mass spectrometry, Environ. Sci. Techno., 30, 385-391, https://doi.org/10.1021/es9407305, 1996.

Hara, K., Osada, K., Yabuki, M., Hashida, G., Yamanouchi, T., Hayashi, M., Shiobara, M., Nishita, C., and Wada, M.: Haze episodes at Syowa Station, coastal Antarctica: Where did they come from?, J. Geophys. Res., 115, D14205, https://doi.org/10.1029/2009JD012582, 2010.

Hara, K., Osada, K., Nishita-Hara, C., Yabuki, M., Hayashi, M., Yamanouchi, T., Wada, M., and Shiobara, M.: Seasonal features of ultrafine particle volatility in the coastal Antarctic troposphere, Atmos. Chem. Phys., 11, 9803-9812, https://doi.org/10.5194/acp-11-9803-2011, 2011.

Hara, K., Osada, K., and Yamanouchi, T.: Tethered balloonborne aerosol measurements: seasonal and vertical variations of aerosol constituents over Syowa Station, Antarctica, Atmos. Chem. Phys., 13, 9119-9139, https://doi.org/10.5194/acp-139119-2013, 2013.

Hu, Q.-H., Xie, Z.-Q., Wang, X.-M., Kang, H., and Zhang, P.: Levoglucosan indicates high levels of biomass burning aerosols over oceans from the Arctic to Antarctic, Sci. Rep., 3, 3119, https://doi.org/10.1038/srep03119, 2013. 
Ito, A., Ito, A., and Akimoto, H.: Seasonal and interannual variations in $\mathrm{CO}$ and $\mathrm{BC}$ emissions from open biomass burning in Southern Africa during 1998-2005, Global Biogeochem. Cy., 21, GB2011, https://doi.org/10.1029/2006GB002848, 2007.

Krinner, G., Petit, J.-R., and Delmonte: Altitude of atmospheric tracer transport towards Antarctica in present and glacial climate, Quaternary Sci. Rev., 29, 274-284, https://doi.org/10.1016/j.quascirev.2009.06.020, 2010.

Li, F., Ginoux, P., and Ramaswamy, V.: Transport of Patagonian dust to Antarctica, J. Geophys. Res.-Atmos. (1984-2012), 115, D18217, https://doi.org/10.1029/2009JD012356, 2010.

Minikin, A., Legrand, M., Hall, J., Wagenbach, D., Kleefeld, C., Wolff, E., Pasteur, E., and Ducroz, F.: Sulfur-containing species (sulfate and methanesulfonate) in coastal Antarctic aerosol and precipitation, J. Geophys. Res., 103, 10975-10990, https://doi.org/10.1029/98JD00249, 1998.

Moorthy, K. K., Satheesh, S. K., Babu, S. S. and Saha, A.: Large latitudinal gradients and temporal heterogeneity in aerosol black carbon and its mass mixing ratio over southern and northern oceans observed during a transcontinental cruise experiment, Geophys. Res. Lett., 32, L14818, https://doi.org/10.1029/2005GL023267, 2005.

Moschos, V., Kumar, N., Daellenbach, K., Baltensperger, U., Prevot, A., and Haddad, I.: Source Apportionment of Brown Carbon Absorption by Coupling UV/Vis Spectroscopy with Aerosol Mass Spectrometry, Environ. Sci. Technol. Lett., 5, 302-308, https://doi.org/10.1021/acs.estlett.8b00118, 2018.

Moteki, N., Adachi, K., Ohata, S., Yoshida, A., Harigaya, T., Koike, M., and Kondo, Y.: Anthropogenic iron oxide aerosols enhance atmospheric heating, Nat. Commun., 8, 15329, https://doi.org/10.1038/ncomms15329, 2017.

Myhre, C. E., D’Anna, B., Nicolaisen, F. M., and Nielsen, C. J.: Properties of aqueous methanesulfonic acid: complex index of refraction and surface tension, Appl. Opt., 43, 2500-2509, 2004.

Neff, P. and Bertler, N.: Trajectory modeling of modern dust transport to the Southern Ocean and Antarctica, J. Geophys. Res.-Atmos., 120, 9303-9322, https://doi.org/10.1002/2015JD023304, 2015.

Novakov, T.: The role of soot and primary oxidants in atmospheric chemistry, Sci. Total Environ., 36, 1-10, https://doi.org/10.1016/0048-9697(84)90241-9, 1984.

Pasteris, D., McConnell, J., Das, S., Criscitiello, A., Evans, M., Maselli, O., Sigl, M., and Layman, L.: Seasonally resolved ice core records from West Antarctica indicate a sea ice source of sea salt aerosol and a biomass burning source of ammonium, J. Geophys. Res.-Atmos., 119, 9168-9182, https://doi.org/10.1002/2013JD020720, 2014.

Pereira, E., Evangelista, H., Pereira, K., Cavalcanti, I., and Setzer, A.: Apportionment of black carbon in the South Shetland Islands, Antarctic Peninsula, J. Geophys. Res.-Atmos. (1984-2012), 111, D03303, https://doi.org/10.1029/2005JD006086, 2006.

Pereira, K., Evanhelista, H., Pereira, E., Simões, J., Johnson, E., and Melo, L.: Transport of crustal microparticles from Chilean Patagonia to the Antarctic Peninsula by SEM-EDS analysis, Tellus B, 56, 262-275, https://doi.org/10.1111/j.1600-0889.2004.00105.x, 2004.

Planchon, F., Boutron, C., Barbante, C., Cozzi, G., Gaspari, V., Wolff, E., Ferrari, C., and Cescon, P.: Changes in heavy metals in Antarctic snow from Coats Land since the mid-19th to the late 20th century, Earth Planet. Sci. Lett., 200, 207-222, https://doi.org/10.1016/S0012-821X(02)00612-X, 2002.

Preunkert, S., Jourdain, B., Legrand, M., Udisti, R., Becagli, S., and Cerri, O.: Seasonality of sulfur species (dimethyl sulfide, sulfate, and methanesulfonate) in Antarctica: Inland versus coastal regions, J. Geophys. Res., 113, D15302, https://doi.org/10.1029/2008JD009937, 2008.

Sakerin, S. M., Smirnov, A., Kabanov, D. M., Pol'kin, V. V., Panchenko, M. V., Holben, B. N., and Kopelevich, O. V.: Aerosol optical and microphysical properties over the Atlantic Ocean during the 19th Cruise of the Research Vessel Akademik Sergey Vavilov, J. Geophys. Res., 112, D10220, https://doi.org/10.1029/2006JD007947, 2007.

Saleh, R., Hennigan, C. J., McMeeking, G. R., Chuang, W. K., Robinson, E. S., Coe, H., Donahue, N. M., and Robinson, A. L.: Absorptivity of brown carbon in fresh and photo-chemically aged biomass-burning emissions, Atmos. Chem. Phys., 13, 76837693, https://doi.org/10.5194/acp-13-7683-2013, 2013.

Saleh, R., Robinson, E., Tkacik, D., Ahern, A., Liu, S., Aiken, A., Sullivan, R., Presto, A., Dubey, M., Yokelson, R., Donahue, N., and Robinson, A.: Brownness of organics in aerosols from biomass burning linked to their black carbon content, Nat. Geosci., 7, 647-650, https://doi.org/10.1038/ngeo2220, 2014.

Schwarz, J. P., Samset, B. H., Perring, A. E., Spackman, J. R., Gao, R. S., Stier, P., Schulz, M., Moore, F. L., Ray, E. A., and Fahey, D. W.: Global-scale seasonally resolved black carbon vertical profiles over the Pacific, Geophys. Res. Lett., 40, 5542-5547, https://doi.org/10.1002/2013GL057775, 2013.

Sciare, J., Favez, O., Sarda-Estève, R., Oikonomou, K., Cachier, H., and Kazan, V.: Long-term observations of carbonaceous aerosols in the Austral Ocean atmosphere: Evidence of a biogenic marine organic source, J. Geophys. Res., 114, D15302, https://doi.org/10.1029/2009JD011998, 2009.

Sharma, S., Leaitch, W. R., Huang, L., Veber, D., Kolonjari, F., Zhang, W., Hanna, S. J., Bertram, A. K., and Ogren, J. A.: An evaluation of three methods for measuring black carbon in Alert, Canada, Atmos. Chem. Phys., 17, 15225-15243, https://doi.org/10.5194/acp-17-15225-2017, 2017.

Shiraiwa, M., Kondo, Y., Moteki, N., Takegawa, N., Miyazaki, Y., and Blake, D. R.: Evolution of mixing state of black carbon in polluted air from Tokyo, Geophys. Res. Lett., 34, L16803, https://doi.org/10.1029/2007GL029819, 2007.

Shirsat, S. V. and Graf, H. F.: An emission inventory of sulfur from anthropogenic sources in Antarctica, Atmos. Chem. Phys., 9, 3397-3408, https://doi.org/10.5194/acp-9-3397-2009, 2009.

Smith, J., Vance, D., Kemp, R., Archer, C., Toms, P., King, M., and Zárate, M.: Isotopic constraints on the source of Argentinian loess - with implications for atmospheric circulation and the provenance of Antarctic dust during recent glacial maxima, Earth Planet. Sci. Lett., 212, 181-196, https://doi.org/10.1016/S0012821X(03)00260-7, 2003.

Stein, A. F., Draxler, R. R, Rolph, G. D., Stunder, B. J. B., Cohen, M. D., and Ngan, F.: NOAA's HYSPLIT atmospheric transport and dispersion modeling system, B. Am. Meteorol. Soc., 96, 2059-2077, https://doi.org/10.1175/BAMS-D-14$00110.1,2015$.

Stohl, A. and Sodemann, H.: Characteristics of atmospheric transport into the Antarctic troposphere, J. Geophys. Res., 115, D02305, https://doi.org/10.1029/2009JD012536, 2010. 
Sudo, K. and Akimoto, H.: Global source attribution of tropospheric ozone: Long-range transport from various source regions, J. Geophys. Res., 112, D12302, https://doi.org/10.1029/2006JD007992, 2007.

Sudo, K., Takahashi, M., Kurokawa, J., and Akimoto, H.: Chaser: A global chemical model of the troposphere, 1. Model description, J. Geophys. Res., 107, 4339, https://doi.org/10.1029/2001JD001113, 2002.

Takemura, T., Nozawa, T., Emori, S., Nakajima, T. Y., and Nakajima, T.: Simulation of climate response to aerosol direct and indirect effects with aerosol transport-radiation model, J. Geophys. Res., 110, D02202, https://doi.org/10.1029/2004JD005029, 2005.

Tomikawa, Y., Nishimura, Y. and Yamanouchi, T.: Characteristics of Tropopause and Tropopause Inversion Layer in the Polar Region, SOLA, 5, 141-144, https://doi.org/10.2151/sola.2009-036, 2009.

Torres, O., Chen, Z., Jethva, H., Ahn, C., Freitas, S. R., and Bhartia, P. K.: OMI and MODIS observations of the anomalous 2008-2009 Southern Hemisphere biomass burning seasons, Atmos. Chem. Phys., 10, 3505-3513, https://doi.org/10.5194/acp10-3505-2010, 2010.

Ueda, S., Osada, K., Hara, K., Yabuki, M., Hashihama, F., and Kanda, J.: Morphological features and mixing states of sootcontaining particles in the marine boundary layer over the Indian and Southern oceans, Atmos. Chem. Phys., 18, 9207-9224, https://doi.org/10.5194/acp-18-9207-2018, 2018.

Vallelonga, P., Velde, K., Candelone, J.-P., Morgan, V. Boutron, C., and Rosman, K.: The lead pollution history of Law Dome, Antarctica, from isotopic measurements of ice cores: 1500 AD to 1989 AD, Earth Planet. Sci. Lett., 204, 291-306, https://doi.org/10.1016/S0012-821X(02)00983-4, 2002.

Vallelonga, P., Gabrielli, P., Balliana, E., Wegner, A., Delmonte, B., Turetta, C., Burton, G., Vanhaecke, F., Rosman, K. J. R., Hong, S., Boutron, C. F., Cescon P., and Barbante, C.: Lead isotopic compositions in the EPICA Dome $\mathrm{C}$ ice core and Southern Hemisphere Potential Source Areas, Quaternary Sci. Rev., 29, 247255, https://doi.org/10.1016/j.quascirev.2009.06.019, 2010.

van der Werf, G. R., Randerson, J. T., Giglio, L., Collatz, G. J., Kasibhatla, P. S., and Arellano Jr., A. F.: Interannual variability in global biomass burning emissions from 1997 to 2004, Atmos. Chem. Phys., 6, 3423-3441, https://doi.org/10.5194/acp-6-34232006, 2006.

Wagenbach, D.: Coastal Antarctica: atmospheric chemical composition and atmospheric transport, in: Chemical Exchange Between the Atmosphere and Polar Snow, NATO ASI Series Volume 43, edited by: Wolff, E. W. and Bales, R. C., SpringerVerlag, Berlin Heidelberg, 173-199, 1996.
Warren, S. G. and Clarke, A. D.: Soot in the atmosphere and snow surface of Antarctica, J. Geophys. Res., 95, 1811-1816, 1990.

Watanabe, S., Hajima, T., Sudo, K., Nagashima, T., Takemura, T., Okajima, H., Nozawa, T., Kawase, H., Abe, M., Yokohata, T., Ise, T., Sato, H., Kato, E., Takata, K., Emori, S., and Kawamiya, M.: MIROC-ESM 2010: model description and basic results of CMIP5-20c3m experiments, Geosci. Model Dev., 4, 845-872, https://doi.org/10.5194/gmd-4-845-2011, 2011.

Wegner, A., Gabrielli, P., Wilhelms-Dick, D., Ruth, U., Kriews, M., De Deckker, P., Barbante, C., Cozzi, G., Delmonte, B., and Fischer, H.: Change in dust variability in the Atlantic sector of Antarctica at the end of the last deglaciation, Clim. Past, 8, 135147, https://doi.org/10.5194/cp-8-135-2012, 2012.

Weingartner, E., Saathoff, H., Schnaiter, M., Streit, N., Bitnar, B., and Baltensperger, U.: Absorption of light by soot particles: determination of the absorption coefficient by means of aethalometers, J. Aerosol Sci., 34, 1445-1463, https://doi.org/10.1016/S0021-8502(03)00359-8, 2003.

Weller, R., Wagenbach, D., Legrand, M., Elsnsser, C., Tian-Kunze, X., and Kónig-Langlo, G.: Continuous 25-yr aerosol records at coastal Antarctica - I: Interannual variability of ionic compounds and links to climate indices, Tellus, 63B, 901-919, https://doi.org/10.1111/j.1600-0889.2011.00542.x, 2011.

Weller, R., Minikin, A., Petzold, A., Wagenbach, D., and König-Langlo, G.: Characterization of long-term and seasonal variations of black carbon (BC) concentrations at Neumayer, Antarctica, Atmos. Chem. Phys., 13, 1579-1590, https://doi.org/10.5194/acp-13-1579-2013, 2013.

Wolff, E. and Cachier, H.: Concentrations and seasonal cycle of black carbon in aerosol at a coastal Antarctic station, J. Geophys. Res., 103, 11033-11041, https://doi.org/10.1029/97JD01363, 1998.

Zangrando, R., Barbaro, E., Vecchiato, M., Kehrwald, N., Barbante, C., and Gambaro, A.: Levoglucosan and phenols in Antarctic marine, coastal and plateau aerosols, Sci. Total Environ., 544, 606616, https://doi.org/10.1016/j.scitotenv.2015.11.166, 2016.

Zhang, X., Liu, Z., Hecobian, A., Zheng, M., Frank, N. H., Edgerton, E. S., and Weber, R. J.: Spatial and seasonal variations of fine particle water-soluble organic carbon (WSOC) over the southeastern United States: implications for secondary organic aerosol formation, Atmos. Chem. Phys., 12, 6593-6607, https://doi.org/10.5194/acp-12-6593-2012, 2012. 